\title{
Cross-Dialectal Synopsis of the Morphosyntax
}

Constructional splits have been a recurrent theme in the discussions of the distinct dialect groups of Neo-Aramaic in the previous chapters, each of which are conditioned by features that have been pertinent to the question of ergativity in linguistic typology. On closer examination, however, these features, though some of them consistent with typological traits of 'split ergativity', need not reflect ergativity nor split alignment in general. While the dialectal diversity of Northeastern and Central Neo-Aramaic shows a staggering degree of morphosyntactic microvariation, there are general motifs in the constructionspecific and dialect-specific constraints that merit a separate chapter to compare these cross-dialectally.

Moreover, splits on some level do not preclude splits on another, so that sometimes subsystems may be observed within constructional splits, including those conditioned by TAM (Section 6.1), morphological coding (Section 6.2), (in) transitivity (Section 6.3.) and referential properties (Section 6.4). In all of this, the morphology of arguments shows the highest degree of variation, always at least in some way linked to the historically resultative participle qțil-, but not exclusively, whereas the general syntax of arguments is largely consistent across space and time. Differential object marking, for instance, is an essential component of the morphosyntax, which seems to be completely blind to the alignment typology of a given dialect, but does seem to favor different combinations of coding strategies depending on the dialect, thus sometimes manifesting morphological splits. The coding of s, in turn, is typically manifested in verbal person marking and correlates with the additional expression of TAM in verbal inflection more strongly than the coding of P. Moreover, the coding of s largely also depends on the lexicalization of transitivity, i.e. whether the intransitive verb or clause in question is compatible with transitive morphology, thereby sometimes resulting in split intransitivity. The L-suffixes are more grammaticalized as indicators of $\mathrm{A}$ in the expression of the transitive perfective past, while the E-suffixes as indicators of $s$ tend to 'lag behind' in the grammaticalization of the intransitive resultative. In addition, the marking of A can be dependent on the properties of its co-argument, P, i.e. the presence or absence of a pronominal object. Thus, perfective past clauses with A and P sometimes show a degree of markedness greater than all other types of clauses. 
TAM can be expressed on three levels of morphological abstraction in NeoAramaic, namely:

a) the preverbal modifier, such as hole, la or na in NENA (see $§ 3.4 .2 ., ~ § 4.1 .2 .2$., § 4.3.1.) or ko in Țuroyo ( $\$ 5 \cdot 3 \cdot 3$.$) ;$

b) the inflectional base, such as qtil-vs. qațal-representing the reflexes of the historical resultative and active participle, respectively;

c) the set of person markers, such as L-suffixes vs. E-suffixes (see $§ 3.4 \cdot 3$., §4.3.1., § 4.4.3.2., §5.4.).

Cross-linguistic surveys of implicational TAM scales for alignment splits conditioned by TAM (e.g. Malchukov 2015) predict that resultative and perfect are the most likely to pattern ergatively against the perfective past and especially the imperfective present and imperative. When the perfective past patterns ergatively, the perfect and resultative are expected to do so as well (see $§$ 3.2.1.2.).

TAM splits in NENA are further complicated by the fact that the two sets of person suffixes, the E-set and L-set, can both be attached to qtil- in denoting $\mathrm{s}$ and/or A in different tense-aspect constructions. They have been built into the TAM system as a means to distinguish TAM categories and reflect different degrees of grammaticalization along the tense-aspect scale of resultative, perfect and preterit, which represents diachronically the grammaticalization from stative-resultative to perfective past (e.g. Bybee and Dahl 1989):

(1) stative $>$ resultative $>$ perfect $>$ perfective past (preterit)

\subsubsection{The Tense-Aspect-Mood Scale}

First of all, the TAM-conditioned split in Neo-Aramaic represents first and foremost a constructional split, which is the end result of specific diachronic developments. The splits in Neo-Aramaic mainly depend on inflectional base:qțil- as opposed to qațal- (or qoțəl- in Central Neo-Aramaic), going back historically to the resultative and active participles respectively. Synchronically, imperfective and perfective aspect are secondary, as verbal constructions are strictly speaking not always dedicated to a single TAM category.

Moreover, the alignment for qțil-, i.e. the 'perfective', may not be different from that of qatal-, i.e. the 'imperfective', but the constructional split is generally characterized by a role reference inversion. Whether this leads to an additional distinction in alignment depends primarily on variation in the coding of $s$ in the relevant dialect(s). Alignment types other than accusative and ergative are conditioned by these inflectional bases; even ditransitive coding was found to be dependent on them (see $\S$ 4.4.2.2. and $\S 5.2 .1 .2$.$) . When there is$ 
a split, however, the accusative is favored in the imperative and irrealis imperfective present constructions.

The 'imperfective', i.e. qațal-, is accusatively aligned, while the 'perfective', i.e. qțil-, patterns ergatively for the third person in SE Trans-Zab Jewish varieties of NENA, both of which are compared below (see §3.3.1.).

(2) J. Sulemaniyya (NE Iraq; Khan 2004a, 2007a)

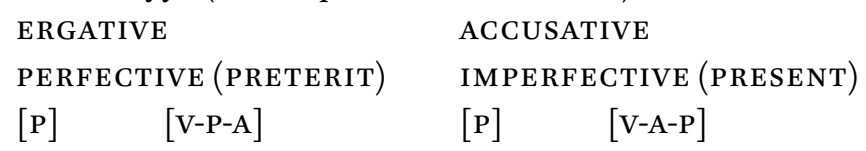

It is mainly the transitive construction that is treated differently, while $s$ is consistent. On the other hand, some subjects of intransitive verbs are compatible with A-like person marking in qțil- (see § 3.5.):
$[\mathrm{s}] \quad[\mathrm{v}-\mathrm{s}]$
e. baxtaké tpal-la
$[\mathrm{s}] \quad[\mathrm{v}-\mathrm{s}]$
'The woman sneezed.'
f. baxtaké tapl-á
'The woman sneezes.'

The differential treatment of intransitive clauses like (2e) above is apparent only in the perfective past. There is no a priori reason, however, to consider the 'imperfective' counterpart in ( $2 \mathrm{f}$.) less transitive in morphosyntax than that in (2e), since there is no morphological device to distinguish A apart from s. Intransitive verbs such as $t p l$ 'sneeze' are therefore arguably compatible with transitive coding in both 'perfective' and 'imperfective' clauses.

SE Trans-Zab Jewish varieties are thus consistent with the implicational TAM scale. If the ergative verbal person marking occurs in the perfective past, it also occurs - albeit to different degrees depending on the dialect—in the realis and irrealis perfect as well as the resultative aspect, which are generally expressed by constructions based on the copula or hwy 'be' and the resultative participle. The same holds for third person pro-indexes in the Neo-Aramaic dialects of Tur 'Abdin, although there the intransitive 'perfective' may show a distinct inflectional base, e.g. damix-o 'She slept' as opposed ftiho 'It $\mathrm{F}_{\mathrm{F}}$ opened'. Third person 
accusative agreement in the perfective past, but ergative agreement in the perfect is possibly found in the Northern Trans-Zab Jewish dialects of NENA (see $\S 3$.4.5.). The feminine participial agreement arguably points to special marking of A. This is only found in the perfect based on the resultative participle qtila.

The Trans-Zab Jewish dialect of Rustaqa and Rewanduz, however, run counter to the TAM scale (see $\S 3.4 .3$ ): the same type of ergative marking as shown in $(2 \mathrm{a}-\mathrm{b})$ is confined to the resultative and perfect based on qțil-. The perfective past shows an accusative grouping of verbal person marking distinct from this. This is an incidental effect of the gradual grammaticalization from resultative to preterit (see further below).

This notwithstanding, the majority of NENA dialects show a purely constructional split, where $\mathrm{S}$ and $\mathrm{A}$ are grouped with distinct affixes. This, in turn, is confined to the third person in the majority of those dialects (see § 4.4.1.). Intransitive 'perfective' clauses are completely distinct from the 'imperfective' only in dialects that systematically group $\mathrm{s}$ and $\mathrm{A}$ by the L-suffixes, as illustrated below. Consequently, accusative alignment as such prevails across TAM categories in the majority of dialects, albeit often limited to the third person.

\section{(3) C. Marga}

\begin{tabular}{|c|c|}
\hline ACCUSATIVE & ACCUSATIVE \\
\hline PERFECTIVE (PRETERIT) & IMPERFECTIVE (PRESENT) \\
\hline$\left[\begin{array}{ll}\mathrm{V}-\mathrm{P} & -\mathrm{A}\end{array}\right] \quad[\mathrm{P}]$ & {$\left[\begin{array}{lll}\mathrm{V}-\mathrm{A} & -\mathrm{P}\end{array}\right] \quad[\mathrm{P}]$} \\
\hline
\end{tabular}

a. xəzy-a -la baxta

'She saw the woman.'

c. $x a z y-a \quad-l a \quad$ baxta

'She saw the woman.'

$\left[\begin{array}{lllll}\mathrm{v} & -\mathrm{s}\end{array}\right][\mathrm{s}] \quad[\mathrm{v}-\mathrm{s}] \quad[\mathrm{s}]$

b. qam -la baxta

'The woman rose.'

d. qaym-a baxta

'The woman rises.'

A few Christian dialects in SE Turkey and Northern Trans-Zab Jewish varieties in Iran express the object with L-suffixes in both the 'imperfective' and 'perfective' (see § 4.4.3.). The primary distinction between the two inflectional systems or TAM constructions, respectively, is the distinct coding of $s$ and $\mathrm{A}$, for example:

(4) J. Urmi (NW Iran; Garbell 1965; Khan 2008b)

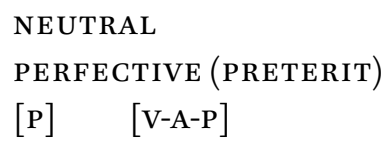

a. baxtá xzé-la-la

'She saw the woman.'
ACCUSATIVE IMPERFECTIVE (PRESENT)

$[\mathrm{P}] \quad[\mathrm{V}-\mathrm{A}-\mathrm{P}]$

c. baxtá xazy-a-la

'She sees the woman.' 

$[\mathrm{s}] \quad[\mathrm{v}-\mathrm{s}]$
b. baxtá qam-la
$[\mathrm{s}] \quad[\mathrm{v}-\mathrm{s}]$
'The woman rose.'
d. baxtá qaym-a
'The woman rises.'

By contrast, the main difference between the 'imperfective' and 'perfective' can be confined to intransitive verbs. The special marking of a by means of the LE series in Western Christian $h$-dialects of NENA in SE Turkey shows partial overlap with the inflection of the 'imperfective' (see § 4.4.4.). Special marking of A by means of the qam-qatal-construction is found across NENA dialects (see $\S$ 4.4.5.). This is completely based on the inflectional base qațal- to express the perfective past. All that is changed is the preverbal TAM-marking, while the morphology specific to qațal-is kept intact, as shown in the comparison below.

(5) J. Dohok (NW Iraq; Molin 2021)

ERGATIVE
PERFECTIVE (PRETERIT)
$\left.\left.\begin{array}{ll}{[\mathrm{V}-\mathrm{A}} & -\mathrm{P}]\end{array}\right] \mathrm{P}\right]$

\section{ACCUSATIVE}

IMPERFECTIVE (PRESENT)

a. qam-xazy-a -la baxta

'She saw the woman.' $\left[\begin{array}{lll}\mathrm{V}-\mathrm{A} & -\mathrm{P}\end{array}\right] \quad[\mathrm{P}]$

c. k-xazy-a -la baxta

'She sees the woman.'

$\left[\begin{array}{lllll}\mathrm{v} & -\mathrm{s} & {[\mathrm{s}]} & {[\mathrm{v}-\mathrm{s}]} & {[\mathrm{s}]}\end{array}\right.$

b. qam -la baxta

'The woman rose.'

d. qem-a baxta

'The woman rises.'

\subsubsection{From Stative-Resultative to Preterit}

Northern and Western Trans-Zab Jewish dialects of NENA and C. Artun and Borb-Ruma in SE Turkey show subject marking that is conditioned by an opposition between resultative or perfect against the perfective past. The alternation between L-set and E-set depends on the inflectional base qțil-, as this is not found elsewhere, e.g. for qațal-. With respect to the third persons, fluid-s marking is observed: $s_{A}$ for the perfective aspect, but $s_{P}$ for the realis perfect, for example:

(6) J. Urmi (NW Iran; Garbell 1965; Khan 20o8b)

$$
\begin{array}{lll}
{\left[\begin{array}{lll}
\mathrm{V} & -\mathrm{P} & -\mathrm{A}
\end{array}\right]} \\
\text { a. } x \partial z y & -\boldsymbol{a} & -l \boldsymbol{a} \\
\text { see }_{\mathrm{PFV}} & -\mathrm{P}: 3 \mathrm{FS} & -\mathrm{A}: 3 \mathrm{FS}
\end{array}
$$

'She saw her.' (lit. Her saw she) 
$\begin{array}{ll}\text { b. }{ }^{+d m a x} & -l \boldsymbol{a} \\ \text { sleepp }_{\mathrm{PFV}} & -\mathrm{s}: 3 \mathrm{FS}\end{array}$

'She went to sleep.' (lit. Her slept)

c. ${ }^{+}$dmix $\quad-\boldsymbol{a}$

sleep $_{\mathrm{PFV}}-\mathrm{S}: 3 \mathrm{FS}$

'She has gone to sleep.' (lit. She slept)
$\left(\mathrm{s}_{\mathrm{A}}\right.$ intransitive preterit $)$

$\left(\mathrm{s}_{\mathrm{P}}\right.$ intransitive realis perfect $)$

The opposition between result-state and dynamic action focus of the intransitive situations correlates with their degree of grammaticalization from resultative to preterit. Intransitive resultative and/or perfect patient-like forms like $d$ mix- $a$ interact with resultative and/or perfect forms based on the enclitic copula and resultative participle. By and large, the patient-like form, i.e. the E-set, will never be higher on the grammaticalization scale from resultative-stative to preterit than the agent-like form, i.e. L-set. There are only subtle differences between dialects in terms of aspect: in Jewish Rustaqa (NE Iraq), both the participial (qțila) and the patient-like qțil-construction express an intransitive resultative-stative, whereas in Jewish Urmi (NW Iran) only the participial construction with the copula can be used to express resultative-statives and the patient-like form denotes the realis perfect (see § 3.4.).

The difference in subject coding is the result of the slower grammaticalization of qțil- + E-set, thereby creating a gap for a transitive realis perfect corresponding to the intransitive resultative/perfect:

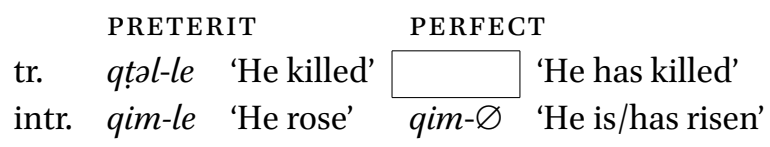

The gap may also be filled by a derivation of the 'perfective' by means of pre-verbal TAM-modification. The TAM marker $l \bar{a}$ together with the $\mathrm{s}_{\mathrm{P}}$ form expresses the resultative-intransitive in J. Rustaqa (NE Iraq). The corresponding transitive perfect is based on qțil-le, as given below (see $\S 3.4 \cdot 3$.).

(8) J. Rustaqa (NE Iraq) PRETERIT PERFECT/RESUltative

tr. qțil-le 'He killed' lā qțil-le 'He has killed'

intr. qim-le 'He rose' lä qim- $\varnothing$ 'He is up, risen'

The difference may be entirely based on the set of person indexes attached to the 'perfective' (qțil-): A and s are grouped by the E-set in the perfect similarly 
to qațal- in C. Borb-Ruma, illustrated below (see § 4.4.3.2.). A similar pattern is documented for Mlaḥsó, although the perfect is distinguished from the preterit by a special inflectional base with a $\mathrm{CaCiC}$-template, qațil- $\varnothing$ 'He has killed' (see $\S 5 \cdot 3.3$.$) .$

(9) C. Borb-Ruma (Bohtan, SE Turkey; Fox 2009) PRETERIT PERFECT

intr. qam-le 'He rose' qim- $\varnothing$ 'He has risen' tr. qtal-le 'He killed' qțil- $\varnothing$ 'He has killed' qtál-le-lā 'He killed them' qțil-i-le 'They have killed him' qtál-li-lux 'I killed you ${ }_{\mathrm{ms}}$ ' qțil-at-li 'You ${ }_{\mathrm{ms}}$ killed me'

In addition, the L-set is used to express object indexes throughout the inflectional system. Consequently, one cannot speak of either a patient-like form or role reference inversion in this dialect, as only the marking of $\mathrm{s}$ and $\mathrm{A}$ are distinguished. The differential expression of A (and s) is unique to qțil-: the E-set expresses A and $\mathrm{s}$ in the realis perfect as it does in qațl- (e.g. xil-a-le 'She has eaten it ${ }_{\mathrm{M}}$ ' $\dot{g} z$-ən-nux ' $\mathrm{I}_{\mathrm{M}}$ have seen you ${ }_{\mathrm{Ms}}{ }^{\text {') }}$, but the L-set expresses all core functions in the perfective past (e.g. $\dot{g} z e ́-l i-l u x ~ ' \mathrm{I}_{\mathrm{M}}$ saw you ${ }_{\mathrm{Ms}}{ }^{\prime}$ ).

The L-E-suffixes in the $h$-varieties in SE Turkey closely related to Borb-Ruma (see $\S 4.3 .1$ and $\S 4.4 .4$.) function similarly to these agent markers in the expression of the perfective past. The insertion of the $l$-morpheme incidentally maintains a distinction between transitive perfect forms like qbil-at-ti ${ }^{\prime} \mathrm{You}_{\mathrm{MS}}$ have received me' and transitive perfective past $q b a l-l-a t-t i{ }^{\prime} \mathrm{You}_{\mathrm{MS}}$ received me' in C. Artun (Hertevin). The transitive perfect, however, seems to be less grammaticalized than in C. Borb-Ruma and patient-oriented perfects are more common, e.g. hil- $a$ ' $\mathrm{It}_{\mathrm{F}}$ was eaten'. This occurs alongside the inverted 'perfective' limited to third person objects, e.g. hil-a-le 'He ate it ${ }_{\mathrm{F}}$ '.

On the whole, the differences in subject coding seem to reflect the degree of grammaticalization from intransitive resultative to perfective past via the perfect (e.g. Bybee and Dahl 1989). The use of the E-set as subject indexes tends to be closely associated with the resultative-stative and/or perfect of the imperfective aspect more so than the use of the L-set as agent indexes to express the perfective past. Khan $(2004,2008 \mathrm{~b}, 2013)^{1}$ argues that this grammatical split is ultimately derived from the lexical split displayed by the aforementioned split-s dialects. Goldenberg (1992,129-130), however, already suggested that the tenseaspectual split is older than the lexical split in SE Trans-Zab Jewish varieties.

1 See also Mengozzi (2005), Doron and Khan (2010, 2012), Barotto (2015), Coghill (2016). 
Khan revised his view in the course of time, so that Khan (2017) is much more in line with the conclusions made here. Following Goldenberg, it seems more plausible to $\mathrm{me}^{2}$ that the resulting incoherence is simply levelled out differently in the respective dialects by the innovation of new transitive realis perfects. Even for the SE Trans-Zab Jewish dialects, it is plausible that the patient-like intransitive resultative ( im- $\varnothing$ 'He is up') grammaticalized via the perfect ('He has risen') to preterit ('He rose'), replacing the preterit, in which s inflected like A (qim-le 'He rose'). The $\mathrm{s}_{\mathrm{A}}$ forms in these dialects, such as ye-le 'He was', $p s ̧ a x$-le 'He rejoiced', are relics of such a former distinction. Language contact with local Iranian languages that show ergative morphosyntax and innovative compound verbal constructions expressing the resultative and/or perfect could have pushed the intransitive resultative into the perfective past. This seems more plausible to me than that the forms with E-suffixes in the preterit 'degrammaticalized' to a resultative (qim- $\varnothing$ 'He rose' > 'He is up, has risen'). There is no independent evidence for this and the development is in itself not straightforward.

\subsection{Morphological Splits}

As across languages of the world and the Semitic family in general, accusative alignment prevails in Neo-Aramaic. The accusative grouping is preferred in both flagging and indexing, but not to the same degree for each coding strategy. The verbal person marking can differ greatly in type and complexity from prepositional marking: alignment splits are rather common in verbal agreement, while prepositional marking patterns accusatively in the majority of dialects. This is most likely connected with the historical development of the morphology: the TAM split in general is the incidental outcome of different sources, whereby the person marking for qțil- originated in the adjectival agreement of an originally resultative participle and developed suffixal person markers, similarly to the corresponding active participle that continues in qațal(see Noorlander forthcoming). In like manner, the possibility of the marking of the agent nominal with the preposition $l$, albeit rather differently in NENA than in Turoyo, and it close link to the L-suffixes only in qțil-is consistent with this unique historical development from a resultative participle with a wide array of argument orientations. ${ }^{2}$ The parallels with L-suffixes in other con-

2 See Noorlander (forthcoming) for further references and argumentation. 
structions, such as ditransitives, can similarly be connected with the historical dative (see Noorlander 2021).

\subsubsection{Prepositional and Verbal Person Marking Entangled}

Independent prepositional object person markers are generally included in the flagging system, which also includes full object NPs (see § 3.1.2. and § 4.1.1.2.) Pronominal ps can be prepositional, sometimes even obligatorily in the perfective past, while it is sometimes impossible for salient nominal ps to be flagged in the same way. Independent objects, and distinct strategies of object marking in general, are required when dependent equivalents are not available, ${ }^{3}$ irrespective of alignment type. In Neo-Aramaic studies, this has been connected with a decline of originally ergative alignment, but it has been demonstrated in the previous chapters that, synchronically, there is no connection with a particular alignment pattern per se. There is, however, a connection with a usage decline of the E-set attached to qțil-, which may be completely obsolete as object markers (see $§$ 4.4.1.2.), and a usage increase of alternative expressions. Restrictions on object coding, however, are not peculiar to qțil-: it also affects for example a set of object indexes related to the 'possessive suffixes' in the imperative in Turoyo (SE Turkey), as discussed in $§$ 5.2.1.2., and the 'possessive suffixes' in the compound perfect or progressive in J. Sulemaniyya (NE Iraq), as discussed in $\S 3.3 .2 .1$.

Similarly, only dependent person markers qualify for cross-indexing, ${ }^{4}$ i.e. those person markers that are attached to the verb can index a coreferential nominal, although some of these are, like the L-suffixes, derived from prepositional pronouns and thus flagged argument indexes having become crossindexes. In particular the 'all-series, originally fully independent like full NPs, may be phonetically reduced and attach to an immediately preceding verb, becoming increasingly dependent on it (e.g. ǵzélox-alleu 'You ${ }_{\mathrm{MS}}$ saw him' for gzelox 'alléu in J. Arbel), which is also irrespective of alignment type (see $\S$ 3.1.2.2. and § 4.4.2.). As dependent person markers, they may be used in the indexing of masculine singular NPs in qțil-alongside the E-set for the feminine singular and common plural, if available. The third person $\varnothing$-morpheme from the E-set, for example, is not used in Jewish Arbel, but the corresponding person form of the 'all-series is the only means to index a masculine singular NP.

3 Unversal G. in Haspelmath (2013, 222).

4 Universals A. and B. in ibid. 
TABLE 39 Splits with prepositional marking of $\mathrm{P}$ in the perfective past

\section{Flagging of NP Indexing of NP Dialects}

\begin{tabular}{|c|c|c|}
\hline $\begin{array}{l}(\mathrm{A}=\mathrm{S}=\mathrm{P}) \text { neutral } / \\
(\mathrm{A}=\mathrm{S} \neq \mathrm{P}) \text { accusative }\end{array}$ & $(\mathrm{A}=\mathrm{S} \neq \mathrm{P})$ accusative & $\begin{array}{l}\text { most of NENA (e.g. J. 'Amedia, } \\
\text { C. Ashitha) }\end{array}$ \\
\hline$(\mathrm{A}=\mathrm{S} \neq \mathrm{P})$ accusative & $(\mathrm{A}=\mathrm{S}=\mathrm{P})$ neutral & $\begin{array}{l}\text { Northern Trans-Zab Jewish NENA } \\
\text { (e.g. J. Urmi), Christian dialects } \\
\text { in SE Turkey (e.g. C. Borb-Ruma), } \\
\text { Mlahısó }\end{array}$ \\
\hline$(\mathrm{A}=\mathrm{S} \neq \mathrm{P})$ accusative & $(A \neq S=P)$ ergative & $\begin{array}{l}\text { Southeastern Trans-Zab Jewish } \\
\text { NENA (e.g. J. Sulemaniyya) }\end{array}$ \\
\hline $\begin{array}{l}(\mathrm{A}=\mathrm{S}=\mathrm{P}) \text { neutral } / \\
(\mathrm{A}=\mathrm{S} \neq \mathrm{P}) \text { accusative }\end{array}$ & $\begin{array}{l}(\mathrm{A} \neq \mathrm{S} \neq \mathrm{P}) \text { tripartite } / \\
(\mathrm{A} \neq \mathrm{S}=\mathrm{P}) \text { ergative }\end{array}$ & Țuroyo \\
\hline$(\mathrm{A}=\mathrm{S}=\mathrm{P})$ neutral & $(\mathrm{A} \neq \mathrm{S}=\mathrm{P})$ ergative & $\begin{array}{l}\text { The majority of NENA dialects with } \\
\text { the qam-qatal-construction }\end{array}$ \\
\hline$(\mathrm{A}=\mathrm{S} \neq \mathrm{P})$ accusative & $(A \neq S=P)$ ergative & $\begin{array}{l}\text { A few NENA dialects with the qam- } \\
\text { qațal-construction (e.g. C. Telkepe) }\end{array}$ \\
\hline
\end{tabular}

Consistent with cross-linguistic tendencies, therefore, flagging and indexing of full NPs usually converge, but some combinations are contrary to this tendency. This is summarized in Table 39 above for splits with object flagging and in Table 40 below for splits with optional agent flagging, respectively; the object marking is conditioned by definiteness in all combinations.

From this we conclude that accusative cross-indexing of full NPs is readily found alongside or combined with accusative flagging in NENA, much like Aramaic in general. Ergative cross-indexing may also be combined with ergative prepositional marking in the 'perfective' in Neo-Aramaic dialects of Tur 'Abdin (see § 5.2.2.). To illustrate: the E-set $i$ in (10) below indexes $P$, and the full nominal is zero-marked like $\mathrm{S}$, while the preposition $(e) l$ - and the L-set mark $\mathrm{A}$; this prepositional marking of $\mathrm{A}$ is optional and often focalizes it.

(10) Țuroyo (Iwardo, SE Turkey; Ritter 1967-1971, 55/11)

[s] [v-s]

a. áh-ḥete nafiq-i

the-wheat:PL go.out $\mathrm{PFv}$-S:3PL

'The wheat went out.' 
TABLE 40 Splits with prepositional marking of $\mathrm{A}($ and $\mathrm{P})$ in the perfective past

\section{Flagging of N P Indexing of NP Dialects}

\begin{tabular}{|c|c|c|}
\hline$(A \neq S=P)$ ergative & $(\mathrm{A} \neq \mathrm{S} \neq \mathrm{P})$ tripartite & $\begin{array}{l}\text { The restricted agentless perfective } \\
\text { in several NENA dialects, mostly } \\
\text { NW Iraq }\end{array}$ \\
\hline $\begin{array}{l}(A=S=P) \text { neutral } / \\
(A \neq S=P) \text { ergative }\end{array}$ & $\begin{array}{l}(\mathrm{A} \neq \mathrm{S} \neq \mathrm{P}) \text { tripartite } / \\
(\mathrm{A} \neq \mathrm{S}=\mathrm{P}) \text { ergative }\end{array}$ & $\begin{array}{l}\text { Both rural and urban Neo-Aramaic } \\
\text { dialects of Țur 'Abdin }\end{array}$ \\
\hline $\begin{array}{l}(\mathrm{A} \neq \mathrm{S}=\mathrm{P}) \text { ergative / } \\
(\mathrm{S} \neq \mathrm{A}=\mathrm{P}) \text { horizontal }\end{array}$ & $(\mathrm{A} \neq \mathrm{S} \neq \mathrm{P})$ tripartite & $\begin{array}{l}\text { The Neo-Aramaic dialect of Rayite } \\
\text { in Țur 'Abdin }\end{array}$ \\
\hline
\end{tabular}
$[\mathrm{P}]$
b. áh-het-ani
$\begin{array}{llll}{[\mathrm{V}} & -\mathrm{P} & -\mathrm{A}] & {[\mathrm{ERG} \rightarrow \mathrm{A}]} \\ \text { xil } & -i & -\boldsymbol{l} e & \boldsymbol{l}-\text { ú-moro }\end{array}$
the-wheat:PL-DEM:PL eat ${ }_{\mathrm{PFV}}-\mathrm{P}: 3 \mathrm{PL}-\mathrm{A}: 3 \mathrm{MS}$ DAT-the-master:MS 'The owner ate this wheat.'

Flagging and indexing can also diverge with respect to alignment. If they do, the person marking is expected to be accusative and the nominal marking to be ergative, while the other way around, i.e. accusative nominal marking but ergative person marking, is virtually non-existent (Comrie 1978, 340; Dixon 1979, 92, 1994, 95-96) (see §3.2.2.).

Across NENA dialects, especially those of early literary texts, which normally group $S$ and A accusatively by the L-set, a focalized agent $N P$ may be marked by $l$ or its dialect-specific allomorphs, in which the verbal qțil-form regularly shows an index of P but never of A (see § 4.2.). Depending on the dialect, such agent focalization constructions are generally interpretable as transitive, although agentless $q t \underline{i l}$-forms can also be impersonal like impersonal passives. The independent prepositional pronoun in the transitive construction in (11) below, for example, is not indexed on the verb (**lälox qțil-êna-lox). The person marking is only ergative in trigger potential, as there is no indexing of A. It is tripartite in morphological marking, however, since $\mathrm{S}$ and $\mathrm{P}$ are morphologically distinct.

(11) Early J. Nerwa (Literary, NW Iraq; Goldenberg 1992, 121)
$[\mathrm{ERG} \rightarrow \mathrm{A}][\mathrm{V} \quad-\mathrm{P}]$
a. läl-ox qțil -ēna
DAT-2MS kill PFV $_{\text {P:1MS }}$
'(It is) you $_{\mathrm{MS}}$ (who) killed me.' 


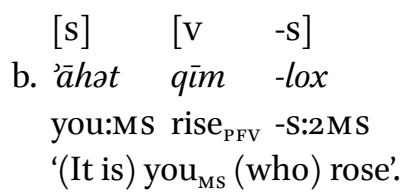

In the Southeastern Trans-Zab Jewish varieties of NENA, the prepositional marking is always accusative and never ergative. The cross-indexing may be ergative, grouping $S$ and $P$ by the E-set in the third person (see $\S 3.3 .1$. ). Both represent two distinct strategies of differential object marking that combine only exceptionally. In Jewish Sulemaniyya, accusative prepositional marking and ergative indexing of full NPs can thus be exceptionally combined in differential object marking:

(12) J. Sulemaniyya (W Iran; Khan 2004a, 326)

$[\mathrm{s}] \quad\left[\begin{array}{ll}\mathrm{v} & -\mathrm{s}\end{array}\right]$

a. yalé zil -i ta-baġdád

child:PL gO $_{\mathrm{PFV}}$-S:3PL DAT-PRN

'The children went to Baghdad.'

$[\mathrm{DOM} \rightarrow \mathrm{P}] \quad\left[\begin{array}{lll}\mathrm{v} & -\mathrm{P}^{5} & -\mathrm{A}\end{array}\right]$

b. lă-yalé labl $-i \quad$-le ta-bagdád

DOM-child:PL take ${ }_{\mathrm{PFV}}-\mathrm{T}: 3 \mathrm{PL}-\mathrm{A}: 3 \mathrm{MS}$ DAT-PRN

'He took the children to Baghdad.'

Neutral, i.e. morphologically non-distinct person marking by the same L-set, also combines with accusative prepositional marking, for example in Northern Trans-Zab Jewish dialects:

(13) J. Urmi (NW Iran; Garbell 1965, 178)

$[\mathrm{s}] \quad[\mathrm{v} \quad-\mathrm{s}]$

a. +šültaná + dmáx - le

'The king slept.'

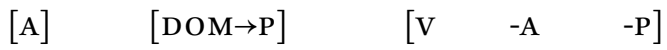
b. +šültaná 'al-brön-éw nšáq $-l e \quad-l e$
king:MS DOM-son:MS-his kiss ${ }_{\mathrm{PFV}}-\mathrm{A}: 3 \mathrm{MS}-\mathrm{P}: 3 \mathrm{MS}$
'The king kissed his son.'

5 Note that, strictly speaking, the verb is ditransitive and yale 'children' is a theme, but it serves to show the possible combination of ergative indexing and accusative case-marking. 
Finally, horizontal prepositional marking by the preposition $(e) l$ - occurs in the village of Rayite in Țur 'Abdin (SE Turkey) (see $\S$ 5.2.2.), but this does not appear to combine with indexing, presumably because of the close structural-and historical—link between the L-set and the preposition $l$-, which typically both mark a full nominal in other constructions such as recipients, predicative possessors, experiencers, alongside definite objects in the imperfective' (see Noorlander 2021).

Verbal person marking can be identified by different criteria, namely morphological marking, i.e. identical person marker sets; relative position, i.e. prefixal or suffixal; and trigger potential, i.e. absent, conditioned or unconditioned. There is a clear preference for accusative alignment in this respect, but the alignment in trigger potential may diverge from that in form. For instance, the ergative grouping of $\mathrm{S}$ and $\mathrm{P}$ in terms of trigger potential is not always consistent with the morphological marking, as shown in the rather exceptional agent focalization in (11) above. The verbal person marking in the preterit in SE TransZab Jewish varieties of NENA, by contrast, is accusative in trigger potential, like the rest of the verbal system, such as qațl-, and only ergative in its morphological marking. The indexing of full nominal ps is overall more restricted and context-dependent than the unconditional indexing of $\mathrm{s}$ and $\mathrm{A}$, for example:

(14) J. Sulemaniyya (NE Iraq; illustration based on Khan 2004a, 2007a, 148149, 154)
[A]
a. goraké
$[\mathrm{P}]$
$[\mathrm{V}(-\mathrm{P}) \quad-\mathrm{A}]$
man:DEF:MS woman:DEF:FS kiss PFv $^{-3 F S}-3 \mathrm{MS}$

b. gora

baxta

$n s ̌ a q(-\varnothing)-l e$

man:Ms

woman:FS

kiss $_{\mathrm{PFV}} \quad-3 \mathrm{MS}$

(indefinite $\mathrm{P}$ )

'A man kissed a woman.'
[s]
[v-s]
c.
baxtaké
qim-a
(definite s)
woman:DEF:FS rise $_{\mathrm{PFV}}-3 \mathrm{FS}$
'The woman rose.'

d.

$$
\begin{array}{ll}
\text { baxta } & \text { qim-a } \\
\text { woman:FS } & \text { rise }_{\mathrm{PFV}}-3 \mathrm{FS}
\end{array}
$$

(indefinites)

'A woman rose.' 
In the final analysis, there are no clear-cut distribution patterns in usage of either object flagging and/or indexing, and the two coding strategies do not appear to be mutually exclusive in monotransitive constructions. First/second person objects may be preferably independent and prepositional, like demonstrative pronouns and full nominals, leading to a person-role constraint in qțil-. Agent flagging, however, is always combined with agent indexing in Țuroyo, while this combination seems to be impossible in NENA.

\subsubsection{Ergative-Like Markedness}

Alignment types are sometimes further differentiated by their relative morphological and functional markedness (see $§$ 4.2.1.). The isolated argument distinct from $s$ in typologically marked systems is realized as $\varnothing$ and/or has a greater potential to trigger overt agreement. The so-called 'marked nominative' and 'marked absolutive' types go against this tendency.

Marked alignment types of prepositional marking have not been observed for neither Northeastern nor Central Neo-Aramaic, since $s$ is, on the whole, never prepositional. The one exception is Turoyo, where the $s$ of a few intransitive verbs may be compatible with $(e) l-$, exactly like A, thereby treating some intransitive verbs as transitive, but this is always accompanied by indexing. Otherwise, the isolated argument, i.e. P or A, is overtly marked in either accusative or ergative prepositional marking, and only rarely both A and P in horizontal prepositional marking.

Markedness considerations could be made with respect to agreement. The possible zero realization and the trigger potential for overt agreement are the main factors in the markedness of agreement. The set of person markers that has most zero realizations is considered an unmarked instance of the expression of s. In Neo-Aramaic, the potential candidate for this would be the E-set, where the $3 \mathrm{~ms}$. form is $\varnothing$, since the L-set does not have any zero realizations. In addition, the trigger potential for overt indexing of person, number and/or gender is the highest for $\mathrm{S}$ and the lowest for $\mathrm{P}$ throughout the verbal system in all dialects, with A coming in between, albeit most often equivalent to s.

Thus, ergative grouping of $\mathrm{s}$ and $\mathrm{P}$ by the E-set is typically only manifested in third person cross-indexes in SE Trans-Zab Jewish varieties of NENA and third person pro-indexes in Turoyo. This is in accordance with expectations of the functional markedness, as the zero realization is only found for the third masculine singular $\mathrm{S}$ and $\mathrm{P}$ : 
(15) J. Saqiz (W Iran; based on Israel 1998)

[v-s]

a. $d$ mix $\varnothing$

(intransitive)

sleep ${ }_{\mathrm{PFV}}-\mathrm{S}: 3 \mathrm{SMS}$

'He slept.' (lit. Slept)

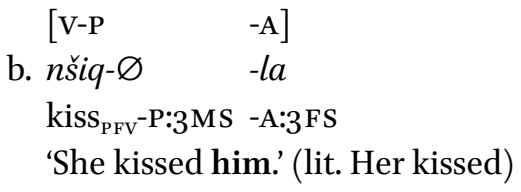

(transitive)

The verb indexes only s and $\mathrm{P}$ in compound perfects in Jewish dialects of Iranian Kurdistan, as illustrated in (16) below (see $§ 3.4 .7$ ). The indexing of P is conditioned by definiteness, while A never triggers agreement, which is typical of ergative systems; the reference of A in this construction is also limited to the third person. Without differential object marking, the clause would be potentially ambiguous, although the P-V word order contributes to argument disambiguation.

(16) J. Saqiz (W Iran; Israeli 1998, 100-101)

$[\mathrm{s}]$

$$
\text { [v-s] }
$$

a. blan-ú dmix-én

daughter:PL-his slept:NONFS-S:3PL

'His daughters slept.' (lit. are slept)
[A]
$[\mathrm{P}]$
[V-P]

b. bronaké ilé

bab-év

nəšq-én

son:MS:DEF hand:PL father:Ms-his kissed:NONFS-P:3PL

'The son kissed the hands of his father.' (lit. are kissed)

The overt vs. zero marking also plays a role in the participial agreement in the compound perfect of Jewish Sulemaniyya (and Halabja) conditioned by gender (see § 3.4.6.). Unlike the closely related Southeastern Trans-Zab Jewish dialects like J. Saqiz above, the person markers always pattern accusatively: the enclitic copula expresses S and A, whereas P is expressed by a different set, namely the 'all-series or the 'possessive suffixes'. The main distinction is between overt agreement for the feminine singular ( $q$ tal-t-) against zero for the plural and the masculine singular $\left(q a t t_{-}-\varnothing_{-}\right)$. In transitive clauses, the feminine singular triggers participial agreement, irrespective of the A or P function of the argument. Thus, ergative alignment is manifested when $\mathrm{P}$ is non-feminine singular and $\mathrm{A}$ is 
feminine singular, while accusative alignment is manifested when $P$ is feminine and $\mathrm{A}$ is non-feminine singular.

(17) J. Sulemaniyya (NE Iraq; based on Khan 2004a)

a. nšaq-t-aw-ye

(ergative agreement with $\mathrm{P}$ )

kissed-P:F S-P:3FS-A:3MS

'He has kissed her.'

b. nšaq-t-ew-ya

(accusative agreement with $\mathrm{A}$ )

kissed-A:FS-P:3MS-A:3FS

'She has kissed him.'

c. šmix-ta-ya

(agreement with s)

watied-S:F S-S:3FS

'She has waited.'

Here, the trigger potential for person and number coding is the same for all grammatical functions, but the overt agreement in gender and number on the participle shifts in the direction of the morphologically marked category, the feminine singular, regardless of the role. The $s$ and the non-participial coding, i.e. the copula and the 'possessive' suffixes, remain unaffected, while A is arguably more marked than $\mathrm{P}$, except when there is ergative agreement, which is consistent with functional markedness.

A contrasting phenomenon results in special marking of A in the compound perfect of Northern Trans-Zab Jewish varieties such as J. Urmi (see §3.4.5.). Only the feminine singular A evinces an additional $/ t /$-element in participial agreement, while other arguments, including feminine singular objects, do not show this morphology. The overt agreement is not just conditioned by gender and number, as it is in Jewish Sulemaniyya, but also conditioned by the A function. If this analysis is correct, the feminine ergative agreement reflects a marked ergative pattern, since only a triggers such agreement morphology. The reason for the absence of such morphology for $\mathrm{s}$ in intransitive constructions is that it has a distinct historical development, being grounded in qțil-and not in the resultative participle qtila.

Secondly, the accusative alignment of dependent person markers in NENA, as illustrated below has been analyzed as 'marked nominative' (Barotto 2015) or 'extended ergative' (Doron and Khan 2012; cf. Mengozzi 2002b, 45, fn. 144) due to a conflation of nominal marking and person marking typology. Clearly, these NENA dialects are typically accusative in terms of trigger potential, but arguably 'marked nominative' in terms of phonological form only because of the $\varnothing$ morpheme of the 3 ms. (see $\S$ 4.2.1.2.), as shown below. 
(18) J. 'Amedia (NW Iraq; adapted from Hoberman 1989, 36, Greenblatt 2o11, 101)
$[\mathrm{v}$
$(\varnothing) \quad-s]$
a. dmix
(Ø) -le
sleep $_{\mathrm{PFV}}$ (P:3MS) -S:3MS
(intransitive)
'He slept.' (lit. Him slept)

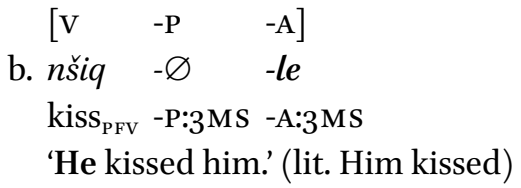
(transitive)

In general the E-set, as object indexes, is more restricted in usage than the L-set in the majority of NENA dialects and may even be confined to the $3 p l .(-i)$ and 3 fs. $(-a)$, so that the zero realization of a third masculine singular object person form is impossible. Perfective past forms like $x z e-l a$ could only mean 'She saw' and not **xze- $\varnothing$-la 'She saw him'. Other strategies to express such objects have to be used, such as the 'all-series in Jewish Arbel ġze-le 'alléu 'He saw him' (NE Iraq; Khan 1999, 119) or the qam-qațal-construction in C. Aradhin qam-xāz-ənne 'I saw him' (NW Iraq; Krotkoff 1982, 28).

In a few NENA dialects that group $\mathrm{S}$ and $\mathrm{A}$ with the L-set, it is possible for the agent NP to be overtly expressed without triggering indexing (Gutman 2008; see $\S 4$.2.). Overt indexing of A is favored in most contexts, whereas absence thereof creates a special truncated transitive construction for dialectdependent purposes, illustrated in (19) below. Although this is a rather marginal phenomenon, the L-suffixes that encode A may be omitted without violating the $P$ status of the patient. The agent receives no coding reference to its role, while a prominent P may still trigger cross-indexing, as exemplified below. The expression of A in this construction is limited and generally restricted to the third person, especially third person plural, much like the impersonal passive.

(19) J. Zaxo (NW Iraq)

$[\mathrm{s}] \quad[\mathrm{v}-\mathrm{s}]$

a. (Ø-)xūrās-e se-lu

friend:PL-his come $_{\mathrm{PFv}}-3 \mathrm{PL}$

'His friends came.' 

[A] $\quad[\mathrm{V}-\mathrm{P}(-\mathrm{A})]$
$[\mathrm{P}]$
b. (Ø-)xūrās-e fhimm-a(-Ø)
$(\varnothing-) z \bar{a} y a \ldots$
friend:PL-his understand $\mathrm{PFv}_{\mathrm{PFV}}-3 \mathrm{FS}(-3 \mathrm{PL})$ matter:FS
'His friends understood the matter ...' (Gutman 2008, 74)

This omission does not apply to s, and often another verb in the immediate context expresses the same topical referent, for example:

(20) C. Ashitha (Literary, NW Iran; Polotsky 1996, 17, transcription modified) te-lay šqil-a $(-\varnothing) \quad$ baxta b-xurțūta $w$-zal-lay come $_{\mathrm{PFV}}-3 \mathrm{PL}$ take $\mathrm{PFv}-3 \mathrm{FS}(-3 \mathrm{PL})$ woman:Fs by-force and-go $\mathrm{PFv}_{\mathrm{PV}}-3 \mathrm{PL}$ 'They came, took the woman by force and went.'

In these phenomena $\mathrm{S}$ and $\mathrm{P}$ are evidently not grouped in morphological marking, i.e. L-set vs. E-set. One could argue that this is an ergative grouping $(\mathrm{A} \neq \mathrm{S}=\mathrm{P})$ only in terms of trigger potential, since only $\mathrm{s}$ and $\mathrm{P}$ are overtly cross-indexed, but not $\mathrm{A}$. The overt indexing of $\mathrm{s}$ and $\mathrm{P}$ but zero indexing of $\mathrm{A}$ is restricted in these dialects with respect to transitive constructions that do show overt agent indexing: A needs to be contextually identifiable, for instance by another preceding or following verbal construction.

Finally, a similar case of absence of overt agreement with the agent in otherwise accusatively aligned constructions is the participial predicate of the compound perfect, where the copula and the participle agree with $\mathrm{s}$ and $\mathrm{A}$, but the third person enclitic copula may also be omitted entirely, so that the participial inflection is the only remaining agent (or subject) coding, e.g.

(21) C. Barwar (NW Iraq)

$\begin{array}{ll}\text { a. } q \text { țil-a(- } \varnothing) & \text { xá-neriye } \\ \text { killed-Ms(-3Ms) } & \text { a-goat:Ms }\end{array}$

'He has killed a male goat.' / 'A male goat has been killed.' ${ }^{6}$ (lit. A-goat killed) (Khan 2008a, A31:4)

The same compound verbal form can also express the passive, so that when the two referents belong to the same gender and number and the patient is not differentially marked, the functions of the arguments have to be inferred from the context. Naturally when the two referents are of distinct gender and number, there is no ambiguity, since A controls the agreement, and word order

6 Or, in theory, 'A male goat has killed (sb.).' 
may contribute to role disambiguation but is not sufficient. Although the agent regularly precedes the verb in A-V-P order, the patient may be focalized to preverbal position (Khan $2008 \mathrm{a}, 75^{2}$ ). The remaining agreement is generally controlled by the agent in P-V-A order, but when the agent also precedes the verb (P-A-V), agreement may be controlled by the patient like the subject, the agent being zero-marked. This resembles the ergative agreement in the compound perfect of the Jewish varieties of Iranian Kurdistan, illustrated in (16).
$[\mathrm{P}]$
[A][-COP:P $] \quad[\mathrm{RPP}-\mathrm{P}]$
b. 'ayya yaloxta
(Ø-)babi-la zqir-ta
DEM:FS handskerchief:Fs father:MS-3FS woven-FS

'This handkerchief has been woven by my father.'7 (lit. This handkerchief my father is woven) (Khan 2008a, A37:12)

On the whole, $\mathrm{s}$ and $\mathrm{A}$ are higher in trigger potential than other functions: agreement with $s$ is always obligatory, and it is mainly third person agents that do not necessarily trigger overt agreement, while this may be impossible or disfavored for the first/second person. The feminine singular is morphologically most salient, and this may even be the sole trigger of agreement irrespective of the argument's function. The masculine singular is generally the least marked of the third person, possibly realized as $\varnothing$, and often identical to the default form when there is no cross-indexing of $P$.

\subsubsection{Role Reference Inversion}

The relative position of A and $\mathrm{P}$ in the affix order is essential to the role reference inversion in qatal-/qțil-. In transitive constructions, the E-set marks A in qațal-, but $\mathrm{P}$ in qțil-, and the other way around for the L-set. The morphemes occur in the same order, but their cross-reference is reversed: the affix order of qațal- is V-A-P, but the reverse, i.e. V-P-A, for qțil-. While a V-P-A order is more common for suffixal person markers that morphologically align accusatively (Siewierska 2004, 167), this is still found for the third person ergative person marking in the SE Trans-Zab Jewish dialects and Țuroyo, alongside accusative person marking in NENA dialects elsewhere. This notwithstanding, there might be a correlation between the V-P-A order and accusative alignment in NENA: it is precisely in those dialects where qțil-groups $\mathrm{S}$ and $\mathrm{A}$ by the L-set that the $\mathrm{V}$ $\mathrm{P}-\mathrm{A}$ order in qțil-is not restricted by person, so that the role reference inversion is complete only in those dialects that are accusative throughout (see $§$ 4.4.1.).

7 Or, in theory, 'This handkerchief has woven my father.' 
There are indications that the affix order may be analogically extended to other verbal constructions, where $\mathrm{P}$ is distinctly marked. Where a person-role constraint restricts V-P-A affix order in qtil-, this may also be found in compound verbal forms denoting the perfect or progressive. In Christian Urmi, the V-P-A order is unrestricted by person in both the preterit and the compound perfect (and progressive), as illustrated in (22a) and (22b) below. Contrast this with Jewish Sulemaniyya in $(22 \mathrm{c}-\mathrm{d})$, where the V-P-A order is confined to third person objects for both the preterit and the compound perfect (and progressive). Although the preterit distinguishes $\mathrm{s}$ from A in J. Sulemaniyya, the progressive does not do so and shows an accusative grouping. Thus, the sequence does not correlate with an alignment type in this respect.

\begin{tabular}{|c|c|}
\hline C. Urmi & J. Sulemaniyya \\
\hline (Literary, NW Iran; & (NE Iraq; \\
\hline Marogulov 1979, 58) & based on Khan 2004a) \\
\hline PRETERIT & PRETERIT \\
\hline$[\mathrm{V}-\mathrm{P}-\mathrm{A}]$ & {$[\mathrm{V}-\mathrm{P}-\mathrm{A}]$} \\
\hline a. šqil-at-li & c. garš-a-le \\
\hline take $_{\mathrm{PFV}}-2 \mathrm{MS}-1 \mathrm{SG}$ & pull $_{\mathrm{PFV}}-3$ FS-3MS \\
\hline 'I took you Ms' $^{\prime}$ & 'He pulled her.' \\
\hline $\begin{array}{l}\text { COMPOUND PERFECT } \\
\text { [V-P-A] }\end{array}$ & $\begin{array}{l}\text { COMPOUND PERFECT } \\
{[\mathrm{V}-\mathrm{P}-\mathrm{A}]}\end{array}$ \\
\hline b. šqúl-ux-van & d. grašt-aw-ye \\
\hline taken-2M S-1MS & pulled:FS-3FS-3MS \\
\hline 'I $\mathrm{M}_{\mathrm{M}}$ have taken you ${ }_{\mathrm{Ms}}$ ' & 'He has pulled her.' \\
\hline
\end{tabular}

A direct correlation for affix order cannot be established, however, since in other dialects, such as C. Shaqlawa (NE Iraq), the inverted v-P-A order is confined to 3 fs. for the preterit, but compound verbal constructions with V-P-A order show no such restrictions. The divergent person role constraints could be accounted for by the different diachronic developments, since the person restrictions on P in qțil-could be motivated by the historical origins of the third person E-set in the participial agreement of an often impersonal construction. This is different from the other strategies, which, for instance, reflect original adnominal possessive suffixes.

The inflection of qațal- penetrates the inflection of qtill-, promoting a V-A-P sequence in several dialects (cf. Mengozzi 20o2b, 46). We observed a possible tendency to normalize the use of the E-set or L-set at the cost of either of the two to encode a specific grammatical function (s, A, P) by morpho- 
logically adapting transitive coding in analogy to qațal-, i.e. the predominant morphosyntax, so that qtil- and qațal-morphology become mixed. Stacked Lsuffixes, the L-E-series and the qam-qatal-construction are alternatives to the E-set analogical to qațal- and seem to be geared to make the L-suffixes in the same V-A-P sequence as that of qatal- the regular expression of pronominal Ps throughout the verbal system, as illustrated in (23) (see § 4.4.)

(23) Alternative strategies to mark $P$

a. qtil

\begin{tabular}{|c|l|}
\hline P & A \\
\hline -E & $-\mathrm{L}$ \\
\end{tabular}

$(\S \S 2 \cdot 3 \cdot 3 \cdot 3,3 \cdot 3 \cdot 1.1$. 4.4.1, 5.1.2.)

\begin{tabular}{|c|c|c|c|c|}
\hline \multirow{2}{*}{ b. qțil } & A & $P$ & \multirow[b]{2}{*}{ prepositional object } & \multirow[b]{2}{*}{$(\S \S 3.3 .2 .1 ., 4.4 .2,5.4 .1)$} \\
\hline & $-\mathrm{L}$ & PP & & \\
\hline c. qțil & $-\mathrm{L}$ & $-\mathrm{L}$ & stacking of L-suffixes & $(\S \S 4.4 \cdot 3,5.2 .1 ., 5 \cdot 3.1)$. \\
\hline d. qțil & $-\mathrm{L}$ & $-\mathrm{L}$ & mixing & $(\S 4.4 \cdot 4 \cdot)$ \\
\hline qțil & $-E$ & $-\mathrm{L}$ & transitive realis perfect & $(\S \S 4.4 \cdot 3.2,5 \cdot 3 \cdot 3 \cdot)$ \\
\hline qam-qațal & $-E$ & $-\mathrm{L}$ & perfective past preverb & $(\S 4.4 .5)$. \\
\hline oqațal & $-E$ & $-\mathrm{L}$ & $\begin{array}{l}\text { (unmarked verbal } \\
\text { inflection) }\end{array}$ & $(\S 2.1)$. \\
\hline
\end{tabular}

These constructions, however, are not necessarily promoting accusative morphosyntax for dependent person markers, ${ }^{8}$ since $\mathrm{s}$, for example, is not affected and generally remains expressed by the L-set. Stacked L-suffixes, for example, manifests a type of neutral alignment, i.e. phonologically non-distinct sets. The L-E-series rather manifests ergative alignment, albeit confined to first/second person agents, and the use of the qam-qațal-construction alongside qțil-results in a pattern that cannot be characterized as accusative either, but we would expect such morphosyntactic transitivity to trigger special marking of $\mathrm{A}$ in an ergative system.

This analogy also inspires morphological adaptation of the compound progressive and perfect on the basis of the morphological parallelism between the first/second person enclitic copulas and the E-set and between the 'all-series and the L-set, respectively. The third person enclitic copula, by contrast, may merge with the L-suffixes. The phonetically reduced forms assimilate more fully to the 'imperfective' when they occur in transitive clauses with two dependent

8 For different analyses, see Mengozzi (2002b, 2005). Khan (2013, 2017), Barotto (2015), Coghill (2016). 
person markers, which incidentally results in the expression of A by morphology distinct from s (see § 3.4.5. and § 4.3.2.4.).

In the end, the morphological split between qațal-and qțil-is the incidental outcome of the original sources: the active and resultative participle, respectively. The inversion reminds us of the active and passive diathesis, because the result state focus of the historical resultative participle * $q t \bar{l} l$ - would often, though not always, have been predicated of the patient. The adoption of a patient-oriented resultative construction into the passive voice system is therefore straightforward, and we still see this reflected in the agentless preterits and possible dative marking of A in several NENA dialects (see $§ 4.2$.). Nevertheless, there are notable differences between these two constructions or participles. While prepositional argument indexes in both fused into L-suffixes synchronically, the historical status of $P$ in the active participle construction and that of $\mathrm{A}$ in the resultative construction were rather different, and the grammaticalization of these constructions would not have proceeded at the same pace: qțil- has lagged behind on qațal- in its grammaticalization and thus transitivization. The prepositional $\mathrm{P}$ of the active participle was a differential object marker, while the prepositional A of the resultative a non-canonical subject marker. Consequently, like other non-canonical subject constructions affected by transitivization, this leads to the gradual loss of agreement with the other, potentially s-like argument in favor of the non-canonical subject. ${ }^{9}$

\subsubsection{What about Ditransitives?}

There is a possibly incidental connection between monotransitives and ditransitive constructions in the combination of dependent person markers across the major constructional split between qțil- and qațal-.

The L-suffixes represent a set of person markers that correlate with the historically dative preposition $(a l / e) l-$, which can still be used to mark goals and recipients. In qațal- and similar verbal constructions such as the imperative, compound progressive etc., the L-set is used to express objects, i.e. P, T, R. In $q$ țil-, however, it is generally confined to the expression of $\mathrm{R}$, depending on the dialect (see $§$ 4.4.3.2.). The use of the L-set to express $\mathrm{R}$ or related affectee roles, such as predicative possessors and experiencers, is therefore independent of this split and may be found across the verbal system, ${ }^{10}$ whereas its use as A indexes remains peculiar to $q$ țil-. Consequently, the coding of $\mathrm{A}$ and $\mathrm{R}$ are identical only in qtil-, and never elsewhere:

9 See Noorlander (2021, forthcoming) for further references and argumentation.

10 See further Noorlander (2021). 
(24) J. 'Amedia (NW Iraq; Hoberman 1989, 108)

$\begin{array}{lll}{[\mathrm{V}-\mathrm{A}} & -\mathrm{R}] & {[\mathrm{T}]} \\ \text { hú-le } & -l i & \text { pare } \\ \text { give }_{\mathrm{PFV}}-\mathrm{A}: 3 \mathrm{MS} & -\mathrm{R}: 1 \mathrm{SG} & \text { money }\end{array}$

'He gave me money.'

In several dialects of NENA in Northwest Iraq and Southeast Turkey, this stacking of L-suffixes is possible only in ditransitive constructions, whereby the second L-suffix denotes only $\mathrm{R}$, even in qațal-forms that take two object indexes from the L-set: the first L-set denotes the theme, the second the recipient. The first L-set, however, is restricted to third person Ts. The stacking of Lsuffixes is more pervasive in dialects with identical morphological marking of $\mathrm{A}$ and $\mathrm{P}$, where the second L-suffixes mark all object types, e.g. hzi-le-li 'They saw me' (C. Jinnet, SE Turkey), which is presumably an extension of its application in qațal. In general, such monotransitive constructions do not display person restrictions on A. Remarkably in C. Artun (Hertevin, SE Turkey), however, this same person restriction on the first L-set occurs everywhere else, where the L-set is stacked, perhaps indicating that there is a connection between the two. Here, the restriction of third person agent indexes before patient indexes parallels the restriction of third person themes before recipient indexes:

(25) C. Artun (Hertevin, SE Turkey; Jastrow 1988, 63)

\begin{tabular}{l|l|ll}
\multicolumn{1}{c|}{} & {$[\mathrm{A}]$} & {$[\mathrm{P}]$} & \\
& {$[3]$} & {$[1,2,3]$} & \\
a. $h z e ́$ & $-l e$ & $-l i$ & 'They saw me.' \\
see $_{\mathrm{PFV}}$ & $3 \mathrm{PL}$ & $1 \mathrm{SG}$ & \\
& & & \\
& {$[\mathrm{T}]$} & {$[\mathrm{R}]$} & \\
& {$[3]$} & {$[1,2,3]$} & \\
b. hál & $-l e$ & $-l i$ & 'Give them to me! \\
give:IMPV & $3 \mathrm{PL}$ & 1SG & \\
\cline { 2 - 3 } & & &
\end{tabular}

This restriction depends entirely on person reference and not on a particular function by itself, as is often the case, since it disfavors both Ts and As, which is a rather unusual combination. Conversely, stacking of L-suffixes is incompatible with third person patients in Turoyo. The second L-suffix of the third person can refer only to R; thus a form like ftáh-li-le conveys 'I opened for him', not 'I opened $i t_{\mathrm{M}}$ '. This is connected with the preference of horizontal alignment for the first/second persons in qtil- where the L-suffix does merge all objects. 
i.e. haé-li-lax 'I saw you ${ }_{\mathrm{Fs}}$ ' = hú-li-lax 'I gave (to) you $_{\mathrm{Fs}}$ '. Only first and second person referents therefore can be treated like $\mathrm{R}$ (see $\S$ 5.2.1.2.).

In a comparable fashion, independent pronominal objects parallel prepositional recipients (see $§$ 4.4.2.2.). An independent series of object person markers may be used in qțil-derived from a dative preposition to express both $\mathrm{P}$ and $\mathrm{R}$, such as ('al)l-:

(26) C. Ashitha (SE Turkey; Borghero 2006, 193, 200-202)

$[\mathrm{V}-\mathrm{A}] \quad[\mathrm{R} / \mathrm{P}] \quad[\mathrm{T}]$

a. hiw-le 'all-i mexulta

give $_{\mathrm{PFV}} \mathrm{-A}$ :3MS DAT-1SG food:FS

'He gave me food.'

b. $x z e-l e \quad$ all-i

see $_{\mathrm{PFV}}$-A:3MS DAT-1SG

'He saw me.'
[V-A-T]
[R]
c. yawal- $\varnothing$-le
'all-i
see $_{\text {IPFV }}$-A:3MS-T:3MS DAT-1SG
'He gives $i_{\mathrm{M}}$ to $\mathbf{m e}$.'

Here, also the inflectional systems differ, since the prepositional object is the favored expression of P only in qțil- but still that of $\mathrm{R}$ in qațal-, in which the L-set remains preferred for $P$.

Finally, the same preposition $l$ - that marks agents in the preterit in Turoyo also marks recipients, predicative possessors and experiencers elsewhere. ${ }^{11}$ The l-marking of A is optional and may indicate additional agent focus, possibly combined with tripartite or ergative person indexing. The identical prepositional marking of both A and P is avoided, similarly to the identical prepositional marking of both $\mathrm{T}$ and $\mathrm{R}$, so that the distribution of indexing of $\mathrm{P}$ and flagging of $\mathrm{A}$ is similar to the indexing of $\mathrm{T}$ and flagging of $\mathrm{R}$ in the ditransitive constructions. Nevertheless, remarkably, identical marking of A and $\mathrm{R}$ is not avoided, which is arguably the situation that would lead to the greatest degree of ambiguity, as both A and $\mathrm{R}$ tend to be human/animate. The Neo-Aramaic dialect of Rayite, however, is the exception: in this dialect, A, P, T and $\mathrm{R}$ can all be marked by the same preposition, similarly to the aforementioned strategies,

11 This could point to a parallel historical development, see Noorlander (2021; forthcoming). 
but there seems to be no additional indexing of $\mathrm{P}$ or $\mathrm{T}$ ( $\mathrm{see} \S 5$ 5.2.2.1.), as is usually the case in other Neo-Aramaic dialects of Tur 'Abdin. The first person plural in Mlahsó is even prepositional in all its functions across the whole system (see $\S 5 \cdot 3 \cdot 1$.$) .$

\subsection{Splits and Transitivity Alternations}

Several Neo-Aramaic languages can employ an agentless form of qtill-, where the agent is not expressed on the verb, but the E-set is used to denote the patient. This construction was analyzed differently depending on dialect group. The verbal form should be interpreted as intransitive in Trans-Zab Jewish dialects of NENA and dialects with dynamic-stative fluid-s marking (see § 3.5.), where no agent can be contextualized, but as transitive in other dialects of NENA, where the agent can still be contextualized (see §4.2.). The morphosyntactic variation reflects the various orientations of the original resultative participle, ranging from subject and patient to agent. The fact that person role restrictions can be uplifted in NENA, when the agent is omitted or becomes prepositional, reflects the original patient orientation of the participle and oblique nature of the agent. In Turoyo, this agentless form of qtil- mainly constitutes an impersonal construction and treats transitive and intransitive verbs alike, being even possible with intransitive verbs (see §5.2.3.2.). Differences in the omission of the patient, in turn, are reflected only in dialects where s may be distinctly marked from A or where clauses with full object nominals show morphosyntax distinct from those without. Moreover, sometimes intransitive verbs can be compatible with transitive coding in the Neo-Aramaic dialects of Tur 'Abdin and Southeastern Trans-Zab Jewish dialects of NENA as well as in the compound verbal forms found in Northern Trans-Zab Jewish dialects of NENA.

\subsubsection{Contextualizing the Agent}

Virtually all basic effective transitive verbs are ambitransitive in the SE Jewish Trans-Zab varieties of NENA. The agentless qțil-form expresses $\mathrm{S}$ and not $\mathrm{P}$, so that constructions like xil- $\varnothing$ ' $\mathrm{It}_{\mathrm{M}}$ got eaten' or qtil- $\varnothing$ 'He got killed' should be ultimately understood as intransitive constructions instantiating an uncontrolled process, just like inchoatives plix- $\varnothing$ ' $\mathrm{It}_{\mathrm{M}}$ opened' and twir- $\varnothing$ ' $\mathrm{It}_{\mathrm{M}}$ broke'.

Similarly, in NENA varieties that betray dynamic-stative fluid-s marking, the agentless form of qțil- should be understood as intransitive. In the Christian dialect of Borb-Ruma (SE Turkey), however, such a patient orientation is never available and an agent orientation is always preferred in order to express the 
perfect, e.g. xil- $\varnothing$ 'He has eaten', ptix- $\varnothing$ 'He has opened'. In the Christian dialect of Artun (Hertevin; SE Turkey), the situation appears to be mixed, and some verbs may allow an agent orientation.

Where ambitransitivity is found in most other dialects of NENA as well as Mlahsó, this is generally not distinct from the accusative pattern in qațl-. If no object index is present, there is no morphosyntactic distinction between a transitive or intransitive valence pattern apart from differential object marking and, in the west, possibly also word order tendencies.

There is also a tendency for object indexes to become a means to differentiate the transitive from the intransitive valence patterns (cf. Givón 1976, 168). For example, when a dialect can avail itself of the qam-qatal-construction for perfective transitive clauses with object indexes, the intransitive valence pattern is always expressed by a qtil-based form, while the transitive valence pattern is ultimately based on qațal- to index P, as illustrated for 'open' in J. Betanure below.

(27) J. Betanure (NW Iraq; Mutzafi 20o8a, 256.399, 266.426)

[s] [V-s]

a. tar'a $^{3}$ ptox-le

(intransitive, inchoative)

door:MS open ${ }_{\mathrm{PFV}}-\mathrm{S}: 3 \mathrm{MS}$

'The door opened.' (lit. him opened)

[V-A-P] [P]

b. qam-pāta-i-le tar'a

PFV-open ${ }_{\text {IPFV }}$-A:3PL-P:3MS door:MS

(transitive, causative)

'They opened the door.' (lit. opened him)

The coding of the intransitive valence pattern can also traverse the TAM split. The intransitive coding is morphologically adapted on the level of stem morphology for passive and anticausatives in the dialect Mlaḥsó, which displays morphologically non-distinct agreement in the preterit and uses a dedicated intransitive construction on the basis of an 'imperfective' mediopassive stem, e.g. mepseh-le 'It ${ }_{\mathrm{M}}$ opened' vs. psih-le 'He opened'. What expresses the difference in TAM is the choice of the E-set or L-set of person markers (cf. mepseh- $\varnothing$ 'It $_{\mathrm{M}}$ opens'). Consequently, special anticausative voice morphology, i.e. $m e \mathrm{CCeC}$-, is used to express the patient orientation in Mlahsó:

tar'ó psį̣ -le 'He opened the door.'

taró mepseh -le 'The door opened.'

(lit. him opened)

(lit. him became open) 
Complete omission of an agent L-suffix is possible only in dialects that minimally group $s$ and A with L-suffixes (see $\S$ 4.2.). It can result in the retention of the transitive coding, sometimes in a type of impersonal passive. This agentless qțil-form expresses the event from the bare viewpoint of the endpoint, as a relic of a formerly patient-oriented resultative that is synchronically a truncated transitive construction (cf. Gutman 2008). The agent's recoverability from the context is decisive in identifying an agent and retaining object coding. It is also possible for this to be a pattern replication from the equivalent agentless and ergative construction in Kurdish.

Țuroyo dialects differ from NENA in this respect. Virtually all verbs, including intransitives, can occur in a type of impersonalization in the mediopassive voice, in which the qțil-form is used in the perfective past of stem I verbs (see $\S$ 5.2.3.2.). Thus, even subject coding may be simply left unexpressed in the qțilform for verbs belonging to the (Ib) * qattili-class, e.g. dmix (- $\varnothing)$ harke 'People (lit. it $_{\mathrm{M}}$ ) slept here' vs. damix- $\varnothing$ harke 'He slept here', while the agent is never overtly expressed in such impersonal constructions. At the same time, Turoyo personal labile alternations manifest third person ergative morphology, thus $f t i h-\varnothing$ ' $\mathrm{It}_{\mathrm{M}}$ opened' or 'People opened it ${ }_{\mathrm{M}}$ ' occurring alongside fta $h$ - $\varnothing$-le 'He opened $\mathrm{it}_{\mathrm{M}}$ '.

The agent may also be omitted in the compound perfect, where the agreement with the agent is generally expressed by the copula and - usually alsothe resultative participle. Insofar as speakers perceive a patient-like argument to be more salient, the construction will not be agent-oriented and the agreement controlled by the patient (see $\S$ 4.2.3.). Indeed, the agreement with the patient and lack of agreement with the agent is crucial to distinction in orientation. The agent can be overtly expressed, and may be morphologically identical to $\mathrm{P}$ in the corresponding active with the dative preposition ('al)l-. A greater structural cohesion between $P$ and the verb are decisive for the active as opposed to passive interpretation, as illustrated below for C. Ashitha.

\begin{tabular}{|c|c|c|c|}
\hline C. Ashitha (NW Iraq; & Borghero 200: & $5,334-336)$ & \\
\hline$[\mathrm{V}-\mathrm{A}]$ & [COP:A] & {$[\mathrm{V}-\mathrm{s}]$} & [COP:S] \\
\hline a. qțil-a & winwa & c. qțil-a & winwa \\
\hline killed-Ms & PST:COP:1MS & killed-MS & PST:COP:1MS \\
\hline${ }^{\prime} \mathrm{I}_{\mathrm{M}}$ had killed (sb.).' & & ' $\mathrm{I}_{\mathrm{M}}$ had be & en killed (by sb.).' \\
\hline
\end{tabular}


There is one respect in which the compound perfect with a patient orientation resembles ergative alignment. When the agent NP precedes the verb, it may be zero-marked like A in some varieties, while the participle and copula still agree with the patient, e.g. C. Barwar baxta ( $\varnothing$-)babi-la qțilta 'The woman has been killed by my father.'12 It is the marked voice opposition that suggests it is passive.

\subsubsection{Recovering the Patient}

Most transitive verbs maintain an agent orientation and show no shift in the coding of the agent in object omission constructions. The agent remains expressed by the L-set. In the Southeastern Trans-Zab Jewish varieties that show split subject marking, the stronger implication of an effect generally results in transitive coding.

Similarly, there are intransitive verbs that occur in an anti-impersonal construction expressing dummy, non-referential (3fs.) object coding. When these verbs combine with a patient-like argument, the subject is coded like A. Light verb constructions reminiscent of noun incorporation in languages with ergative alignment also occur where the intransitive or transitive verb takes a dummy nominal object element, most of which are transferred from Persian and/or Kurdish combining with 'wl 'do' or $x \varnothing r$ 'become' (e.g. Khan 2009, 153). This is different from other languages that evince ergative alignment, where non-referential dummy objects favor intransitive coding (Givón 1985a).

A few verbs, however, do display a difference reminiscent of antipassive voice constructions typical of certain languages with ergative alignment (see $\S 3.5 .2$.), where a semantically agent-like $\mathrm{s}$ is expressed distinct from $\mathrm{A}$. The antipassive-like construction tends to express situations with semantically reduced transitivity. In NENA, the antipassive-like intransitive construction involves a decrease in the degree of affectedness on the part of the patientlike argument, and may also be used to express reflexives. In terms of aspect, the intransitive ('antipassive') verbal forms can express a durative activity, while the transitive ('active'/'ergative') refers to a punctual activity. The durative aspect correlates with the imperfective aspect constructions, where A and $s$ are also marked by the E-set.

Non-human agents are not always compatible with the A function, for which the antipassive-like form is preferred. The antipassive may be enhanced with a patient-like argument coded as oblique:

12 Or, in theory, 'The woman has killed my father.' 
(29) J. Sanandaj (W Iran; Khan 20o9, 522)

$[\mathrm{A}] \quad[\mathrm{V}-\mathrm{A}] \quad[\mathrm{P}]$

a. hangăké nqas-la 'al-í

(ergative)

bee:FS:DEF prick ${ }_{\mathrm{PFv}}-\mathrm{A}: 3 \mathrm{FS}$ OBJ-1SG

'The bee stung me.'

$[\mathrm{s}] \quad[\mathrm{v}-\mathrm{s}]$

b. xmatá nqis-a

needle:Fs:DEF prick ${ }_{\mathrm{PFv}}$-S:3FS

'The needle pricked.'

$[\mathrm{s}] \quad[\mathrm{v}-\mathrm{s}] \quad[\mathrm{OBL}]$

$\begin{array}{lll}\text { c. } x \text { matá } & \text { nqis-a } a \text {-'il-í } \\ \text { needle:Fs:DEF } & \text { prick } \\ \text { PFv } & \text { S:3Fs } & \text { at-hand-my }\end{array}$

(antipassive)

'The needle pricked (lit. at) my hand.'

Similarly, human agents can be coded like A in both constructions, but when the human agent does not act deliberately, it is not always compatible with A-like coding, which shows that the degree of control is a contributing factor to compatibility with transitive coding. Thus, sporadically an alternation may occur where the A-like coding entails that the human argument deliberately initiated an action, while absence thereof rather conveys that something happened to the human argument, e.g.

(30) J. Sanandaj (W Iran; Khan 2009, 304, 543)

a. 'ó rába mandixané ylap-le

(controlled, more A-like)

he many thing:PL learn $_{\mathrm{PFv}}-\mathrm{A}: 3 \mathrm{MS}$

'He learnt many things (by himself).'

b. ’ó rába mandixané yálip- $\varnothing$

(uncontrolled, not A-like)

he many thing:PL learn ${ }_{\mathrm{PFV}}-\mathrm{S}: 3 \mathrm{MS}$

'He learnt many things (when taught by somebody else).'

Turoyo differs in several respects from NENA (see $§$ 5.2.). In Țuroyo, several socalled 'neuter' verbs can combine with a P in the same way as the 'imperfective', e.g. šami-o-le 'She heard him', but differently from primary transitive verbs such as $q t l$ ' 'kill' and twr 'break', which more strongly imply an effect, e.g. twir-o-le 'He broke it ${ }_{\mathrm{F}}$. Primary transitive verbs may be incompatible with the antipassive in other languages, such as Samoan, where ergative morphosyntax predominates: the antipassive, where the agent is distinct from $\mathrm{A}$, is lexicalized for 
verbs not belonging to the primary effective class. The agent-like argument in this $\mathrm{CaCiC}$-perfective in Turoyo is strictly speaking not an A either, but more commonly an affectee of some kind that can be analyzed as an instance of $s$, although the pattern in itself can occur with controlled activities, e.g. šagil$o$ 'She worked', raqid-o 'She danced', yalif-o 'She learned'. These 'neuter' verbs rarely alternate with primary transitive verbs, do not express a passive orientation of a corresponding transitive and never seem to have a strong implication of a patient-like effect. They constitute a special subclass of lexically intransitive verbs, sometimes compatible with transitive morphology, but generally not the A-like coding of primary transitives. Thus, while third person ergative alignment is used only with primary transitive verbs in Țuroyo, a subclass of verbs can never occur with such coding and require a $\mathrm{C} a \mathrm{CiC}$-perfective, even when there is an object, i.e. the intransitive coding is primary. A few of such 'neuter' verbs in Turoyo, however, may sporadically also be found to be compatible with A-like coding depending on what appears to be punctuality, in which case the A-like coding seems to be preferred for the punctual reading.

At the same time, this system in Turoyo could indicate an instance where it is the intransitive coding that overrides alignment splits. In some languages where the alignment is split conditioned by TAM, the (ergative) transitive coding is preferred for primary transitive verbs, such as 'break', even in the TAм constructions where other transitive verbs would follow a different (non-ergative) pattern (Givón 1984a). In Ṭuroyo, it would be the other way around: the primacy of an intransitive verbal class favors non-ergative coding irrespective of TAM (see § 5.4.).

By contrast, most strategies to mark P differently from the E-set in qtil-are morphologically parallel with qatal- in NENA. In some cases, the coding of the agent is also modified. An extreme case we discussed is the qam-qațalconstruction, not found in the Trans-Zab Jewish dialect bundle nor Central Neo-Aramaic, which also correlates with transitivity alternations (see $§ 4.4 .5$.$) .$ In contradistinction to the above, this construction is not dependent on verbal class, but on the nature of object coding and thus morphological transitivity. Reviewed below, the qam-qatal-construction combines with a pronominal object and is used in dialects where $\mathrm{S}$ and $\mathrm{A}$ are grouped by the L-set in the perfective past:

(31) J. Betanure (NW Iraq; based on Mutzafi 20o8a, compare p. 266.426 and 239.440)
$\left[\begin{array}{ll}\mathrm{v} & -\mathrm{s}\end{array}\right]$
a. $x a l \quad-l e$
(intransitive)
eat $_{\mathrm{PFV}}-\mathrm{S}: 3 \mathrm{MS}$
'He ate.' 

$\left[\begin{array}{lll}\mathrm{V} & -\mathrm{A}\end{array}\right] \quad[\mathrm{P}]$
b. $x a l \quad-l e \quad x a b u ̄ s ̌ a$
eat $_{\mathrm{PFV}}$-A:3MS apple:FS
(tr. but identical to intr.)
'He ate an apple.'
c. qam-'āxal- $\varnothing \quad-l a \quad x a b u ̄ s ̌ a \quad$ (tr. but distinct from intr.) PFV-eat ${ }_{\text {IPFV }}$-A:3MS -P:3Fs apple:FS
'He ate the apple.'

This is the opposite of an antipassive voice construction and reminiscent of the applicative voice, where the patient is - in this case has to be-promoted to object status. In the antipassive, the coding of the agent is typically distinct from the $\mathrm{A}$ of the transitive valence pattern in the absence of a certain object type. In the qam-qatal-construction, the coding of the agent is necessarily distinct from $\mathrm{s}$ in the presence of an object index, while the agent in the qtalle counterpart is necessarily the same as $\mathrm{s}$ in the absence of such an object index. It indirectly results in a major distinction in the coding of the agent when $P$ is expressed by an object index. The morphosyntax of transitive clauses without an object index is not distinguishable from intransitive clauses. Nevertheless, transitive clauses that include an object index are morphologically adapted to the transitive coding of qatal-. Therefore, the qamqațal-construction is arguably the more transitive one in being incompatible with object omission constructions, so that here, in theory, it is qtalle that could be said to parallel the antipassive.

\subsubsection{Split Intransitivity}

In Țuroyo, the (Ib) subclass never takes A-like coding, but only other classes can combine with A-like coding, including those semantically intransitive. Only in Țuroyo this also affects the optional flagging of s, treating it like the A of a primary transitive perfective past construction, as illustrated below.

(32) Țuroyo (Rayite, SE Turkey)

a. (Ø-)Hasan Paša mayat- $\varnothing$ PRN:MS $\quad$ die $_{\mathrm{PFV}}-\mathrm{S}: 3 \mathrm{MS}$

'Ḥasan Paša died.' (Ritter 1967-1971, 96/26)

b. l-Nari malax-le

DAT-PRN:MS walk ${ }_{\mathrm{PFV}} \mathrm{-S}: 3 \mathrm{MS}$

'Nari walked.' (ibid. 1. 229) 
Generally, the intransitive verbs that are incompatible with transitive coding are those that typically denote an affectee of a state or uncontrolled process, such as 'die', but there are noteworthy exceptions, for instance the copula verb hwy 'be, become' in Southeastern Trans-Zab Jewish varieties of NENA, e.g. -yele 'he was', and in the Neo-Aramaic dialect of Midyat, e.g. hwele 'it arose', -we $(<$ *hwele $)$ 'he was'.

Semantic factors play only a partial role, since by and large when a transitive verb denotes a semantically less transitive event, but still strongly implies some effect and denotes a punctual and dynamic event, the construction remains morphosyntactically transitive, even when no patient-like effect is expressed explicitly. Semelfactives, especially animal sound emissions, such as 'bark', and more or less controllable bodily emissions and reactions, such as 'sneeze' and 'laugh', generally prefer transitive coding, which is typical of some languages with ergative alignment (cf. Lazard 1998, 136-139; see § 3.5.).

Causal factors pertaining to agentivity sometimes play a role in Southeastern Trans-Zab Jewish dialects of NENA in western Iran. Control or animacy may sometimes determine compatibility with $\mathrm{s}_{\mathrm{A}}$ coding, where a lesser degree of control is not always considered compatible with $\mathrm{s}_{\mathrm{A}}$ coding for the verbs 'sneeze' and 'cough'; compare:

(33) J. Qarah Ḥasan (W Iran; Khan 2009, 306)

a. nox-le ' $\mathrm{It}_{\mathrm{M}}$ barked.'

$(\mathrm{s}=\mathrm{A}$, controlled $)$

b. tpil- $\varnothing$ 'He sneezed.'

$(\mathrm{s}=\mathrm{P}$, uncontrolled $)$

An inanimate subject, such as a natural force, is also not always compatible with $\mathrm{s}_{\mathrm{A}}$ coding either:

(34) J. Sanandaj (W Iran; Khan 2009, 294, 304-306)

$[\mathrm{s}] \quad\left[\mathrm{V}-\mathrm{s}_{\mathrm{A}}\right]$
a. xmara sre-le
$(\mathrm{s}=\mathrm{A}$, animate $)$
donkey:Ms bray ${ }_{\mathrm{PFv}}-3 \mathrm{MS}$
'The donkey brayed.'
$[\mathrm{s}] \quad\left[\mathrm{v}-\mathrm{s}_{\mathrm{P}}\right]$
b. 'ewá gargám- $\varnothing$
cloud:Ms thunder ${ }_{\mathrm{PFv}}-3 \mathrm{MS}$
'The cloud thundered.'
$(\mathrm{S}=\mathrm{P}$, inanimate $)$

Verbs that denote controlled activities show notable differences. When the verb can combine with a $P$, the agent-oriented construction, where $P$ is omitted and 
not expressed explicitly, generally takes the same A-like coding. When verbs of dress and grooming are used intransitively, the meaning can be reflexive without distinction in subject coding (e.g. lwəš-le 'He dressed'). Typologically speaking, such controlled activities would be expected to be $\mathrm{s}_{\mathrm{A}}$ verbs (Croft 2001, 162-165). Nevertheless, numerous intransitive verbs that denote controlled activities are incompatible with such transitive coding, such as 'dance' and 'laugh'. Turoyo and NENA closely resemble each other in this respect: only a few of such activities, such as 'swim', take $\mathrm{s}_{\mathrm{A}}$ coding in Țuroyo (shele), but do not take this in NENA (saxe- $\varnothing$ ). The overall similar distribution in Turoyo and NENA (see $§ 5.2 .3$.) is likely not incidental and parallels the categorization of stative and middle verbs in other Aramaic and Semitic languages.

Aspectual factors also play an important role. Durative and stative situations are in general not compatible with transitive coding, while punctual and dynamic situations may more readily be compatible. Telicity does not appear to be a significant trigger. An intransitive verb like tym 'finish' entails the cessation of an action and is more state and endpoint-oriented, and cannot be combined with transitive coding. An intransitive verb like $b d y$ 'begin', however, which is inherently more action and agent-oriented, does take such transitive inflection.

Fluid-subject marking may also be conditioned by aspect, in which punctuality seems to be a possible contributing semantic factor in Țuroyo. The $\mathrm{s}_{\mathrm{A}}$ construction is compatible with a more punctual reading:

(35) Țuroyo (SE Turkey; Ritter 1990, 85)

a. $k f l-l e^{13} \quad$ 'He became hungry'

$\left(\mathrm{s}_{\mathrm{A}}\right.$, punctual $)$

b. kafan- $\varnothing$ 'He starved'

( $s_{\mathrm{P}}$, durative)

Finally, we noted that a split in the coding of $s$ is also attested for non-ergative alignment (see §3.5.4.). In the Jewish Urmi compound perfect, the coding of $\mathrm{s}$ and $\mathrm{A}$ is distinct for the third person. Some semantically intransitive verbs are classified like primary transitive verbs and take transitive coding instead. The resulting split parallels Southeastern Trans-Zab Jewish. The main typological difference is the treatment of controlled activities, such as 'dance', which do take transitive coding in Jewish Urmi, e.g. rqil-é 'He has danced', but intransitive in the SE Trans-Zab Jewish dialects. Conversely, semelfactives or sound emission verbs, such as 'bark', take intransitive coding in Jewish Urmi, e.g. $n w i x-\varnothing$ ' $\mathrm{It}_{\mathrm{M}}$ barked', but transitive in the SE Trans-Zab Jewish dialects.

$13<* k f a n-l e$. 
TABLE 41 Overview of morphological person splits in the perfective past

\begin{tabular}{|c|c|c|c|}
\hline Independent & $\begin{array}{l}\text { 3rd person } \\
\text { (qtil-P-A) }\end{array}$ & $\begin{array}{l}\text { 1st/2nd person* } \\
\text { (V-A-P) }\end{array}$ & Dialects \\
\hline $\begin{array}{l}(\mathrm{A}=\mathrm{S}=\mathrm{P}) \text { neutral } / \\
(\mathrm{A}=\mathrm{S} \neq \mathrm{P}) \text { accusative }\end{array}$ & $\begin{array}{l}(\mathrm{A}=\mathrm{S} \neq \mathrm{P}) \\
\text { accusative }\end{array}$ & $\begin{array}{l}(\mathrm{A}=\mathrm{S} \neq \mathrm{P}) \\
\text { accusative }\end{array}$ & $\begin{array}{l}\text { Several NENA dialects } \\
\text { (e.g. J. Challa, J. Barzani, } \\
\text { J. Arbel, C. Marga) }\end{array}$ \\
\hline $\begin{array}{l}(\mathrm{A}=\mathrm{S} \neq \mathrm{P}) \\
\text { accusative }\end{array}$ & $\begin{array}{l}(\mathrm{A}=\mathrm{S} \neq \mathrm{P}) \\
\text { accusative }\end{array}$ & $\begin{array}{l}(\mathrm{A}=\mathrm{S}=\mathrm{P}) \\
\text { neutral }\end{array}$ & $\begin{array}{l}\text { Northern Trans-Zab Jew- } \\
\text { ish dialects of NENA (e.g. } \\
\text { J. Urmi) }\end{array}$ \\
\hline $\begin{array}{l}(\mathrm{A}=\mathrm{S} \neq \mathrm{P}) \\
\text { accusative }\end{array}$ & $\begin{array}{l}(A \neq S=P) \\
\text { ergative }\end{array}$ & $\begin{array}{l}(\mathrm{A} \neq \mathrm{S} \neq \mathrm{P}) \\
\text { tripartite }\end{array}$ & $\begin{array}{l}\text { J. Sulemaniyya and Halabja } \\
\text { (NE Iraq) }\end{array}$ \\
\hline $\begin{array}{l}(\mathrm{A}=\mathrm{S} \neq \mathrm{P}) \\
\text { accusative }\end{array}$ & $\begin{array}{l}(\mathrm{A} \neq \mathrm{S}=\mathrm{P}) \\
\text { ergative }\end{array}$ & $\begin{array}{l}(\mathrm{S} \neq \mathrm{A}=\mathrm{P}) \\
\text { horizontal }\end{array}$ & $\begin{array}{l}\text { J. Saqiz and Sanandaj (W } \\
\text { Iran) }\end{array}$ \\
\hline $\begin{array}{l}(\mathrm{A}=\mathrm{S}=\mathrm{P}) \text { neutral } / \\
(\mathrm{A} \neq \mathrm{S}=\mathrm{P}) \text { ergative }\end{array}$ & $\begin{array}{l}(A \neq S=P) \\
\text { ergative }\end{array}$ & $\begin{array}{l}(\mathrm{S} \neq \mathrm{A}=\mathrm{P}) \\
\text { horizontal }\end{array}$ & Țuroyo (SE Turkey) \\
\hline $\begin{array}{l}(\mathrm{A}=\mathrm{S}=\mathrm{P}) \\
\text { neutral }\end{array}$ & $\begin{array}{l}(\mathrm{A}=\mathrm{S} \neq \mathrm{P}) \\
\text { accusative }\end{array}$ & $\begin{array}{l}(\mathrm{A} \neq \mathrm{S}=\mathrm{P}) \\
\text { ergative }^{* *}\end{array}$ & $\begin{array}{l}\text { C. Artun, Umra and Jin- } \\
\text { net (SE Turkey), with the } \\
\text { L-E-series }\end{array}$ \\
\hline $\begin{array}{l}(\mathrm{A}=\mathrm{S}=\mathrm{P}) \\
\text { neutral }\end{array}$ & $\begin{array}{l}(\mathrm{A}=\mathrm{S} \neq \mathrm{P}) \\
\text { accusative }\end{array}$ & $\begin{array}{l}(A \neq S=P) \\
\text { ergative }\end{array}$ & $\begin{array}{l}\text { The majority of NENA } \\
\text { dialects, with the qam- } \\
\text { qațal-construction }\end{array}$ \\
\hline
\end{tabular}

Notes: *This is generally available for all persons in NENA. *Second person only in C. Umra and Jinnet.

Presumably, telicity and dynamism play a greater role than punctuality in the Jewish Urmi perfect (Khan 2008b, 73).

\subsection{Splits Based on Argument Properties}

The splits based on the referential properties of arguments, such as person primarily, are first and foremost a constructional split and have no direct bearing on ergativity. A particular set of argument indexes, namely the E-set, is gradually being replaced depending on the dialect. The same constraint simply works out differently in each dialect (group), and what is pertinent to alignment is only the marking of $\mathrm{s}$ and its relationship to other core arguments, although sometimes also the similar treatment of A and P. Table 41 above pro- 
TABLE 42 Overview of person and gender-based morphological splits in the 'perfect', including compound perfect forms

3rd person 1st/2nd person Dialects

\begin{tabular}{|c|c|c|}
\hline $\begin{array}{l}(\mathrm{A}=\mathrm{S} \neq \mathrm{P}) \\
\text { accusative }\end{array}$ & $\begin{array}{l}(\mathrm{A}=\mathrm{S} \neq \mathrm{P}) \\
\text { accusative }\end{array}$ & The majority of NENA dialects \\
\hline$(\mathrm{A} \neq \mathrm{S} \neq \mathrm{P})$ & $(\mathrm{A}=\mathrm{S} \neq \mathrm{P})$ & Northern Trans-Zab Jewish dialects of \\
\hline tripartite & accusative & NENA \\
\hline$(\mathrm{A} \neq \mathrm{S}=\mathrm{P})$ & $(\mathrm{A} \neq \mathrm{S} \neq \mathrm{P})$ & J. Rustaqa and Rewanduz and SE Trans- \\
\hline ergative & tripartite & Zab Jewish NENA \\
\hline$(\mathrm{A} \neq \mathrm{S}=\mathrm{P})$ & $(\mathrm{S} \neq \mathrm{A}=\mathrm{P})$ & Turoyo (perfect is identical to preterit) \\
\hline ergative & horizontal & \\
\hline
\end{tabular}

Non-feminine Feminine

Dialects

\begin{tabular}{|c|c|c|}
\hline $\begin{array}{l}(\mathrm{S} \neq \mathrm{A}=\mathrm{P}) \\
\text { horizontal }\end{array}$ & $\begin{array}{l}(\mathrm{A} \neq \mathrm{S}=\mathrm{P}) \text { ergative } / \\
(\mathrm{A}=\mathrm{S} \neq \mathrm{P}) \text { accusative }\end{array}$ & J. Sulemaniyya and Halabja (NE Iraq) \\
\hline$=\mathrm{S} \neq \mathrm{P})$ & $(\mathrm{A} \neq \mathrm{S}=\mathrm{P})$ & Northern Trans-Zab Jewish dialects of \\
\hline accusative & ergative & NENA \\
\hline
\end{tabular}

vides an overview of the person-based alignment splits in the preterit, alongside independent pronoun alignment. Table 42 offers an overview of personand/or gender-based splits in the perfect. These tables offer a simplified summary and should not be mistaken for balanced splits, as these person splits do not always distinguish neatly between first/second person as opposed to third person and are not always complementary in NENA dialects. Independent pronouns, and full nominals for that matter, do not pattern ergatively in C. Artun (Hertevin), even though the dependent first/second person markers point to ergative alignment. In several dialects, independent object person markers, like the 'all-series, are preferred, especially for the first/second person, treating them like full nominals.

\subsubsection{Patient-Related Scales}

In general, Central and Northeastern Neo-Aramaic dialects make a distinction between several transitive perfective past constructions depending on the relative ranking of $\mathrm{P}$ on the prominence scale. qțil-and qațal- show considerable overlap in terms of differential indexing and prepositional marking patterns. 
Irrespective of alignment type, a prominent-primarily definite $-\mathrm{P}$ generally determines the prepositional marking and/or overt expression of crossindexes of P. Example (36) is an illustration of such DoM constructions in qtil- based on the morphological pattern of Trans-Zab Jewish varieties (see $\S$ 3.3.2.). Differential object flagging and indexing can occur independently or combined.

\section{(36) Differential object marking in Trans-Zab Jewish varieties of NENA}
[A]
$[(\mathrm{DOM} \rightarrow) \mathrm{P}] \quad[\mathrm{V}(-\mathrm{P})-\mathrm{A}]$
a. hatán 'al-kaldá nšaq-le groom:MS DOM-bride:Fs kiss ${ }_{\mathrm{PFv}}-3 \mathrm{MS}$
b. hatán kaldá nəšq-a-le groom:Ms bride:FS kiss $_{\mathrm{PFv}}-3 \mathrm{FS}-3 \mathrm{MS}$
c. hatán 'al-kaldá nəšq-a-le groom:MS DOM-bride:Fs kiss $\mathrm{PFv}^{-3}$ FS-3MS (prepositional marking only) (cross-indexing only) (both strategies) 'The bridegroom kissed the bride.'

Differential prepositional marking by itself does not generally lead to distinct alignment types across dialects, since, by and large, A is not marked prepositionally. Accusative DOM may sometimes even involve several prepositions in a single dialect, e.g. $q a-, t l a$ - and $l$ - in Barwar (Khan 2008a, 784 ff.). Incidentally, it results in horizontal prepositional marking $(\mathrm{S} \neq \mathrm{A}=\mathrm{P})$ in the Rayite dialect of Țuroyo.

At first face value, this is remarkable, since one would not expect a grouping with $\mathrm{S}$ and $\mathrm{P}$ to be dependent on differential object marking. Differential P-marking is usually associated with non-ergative patterns, precisely because the properties of $\mathrm{P}$ are central to its overt expression and not A (see § 3.2.2.). Nevertheless, where the referential properties of $\mathrm{P}$ are relevant for ergativity, we could expect the ergative construction to be favored for the definite object (see § 4.4.1.1.). The fact that all sorts of morphological alignment types are compatible with DOM in NENA dialects need not surprise us, since the coding of $s$ is independent of such referential factors: it simply demonstrates, that, although the conditioning factor is accusative, differential object marking is not confined to an accusative morphological expression thereof (cf. Bossong 1985). Thus, differential object marking by the preposition ('al)l-is found alongside object indexing that is accusative, neutral and ergative in its morphology. From the perspective of the variation within NENA, this possible combination of ergative indexing and accusative flagging such as shown in Southeastern Trans-Zab Jewish varieties of NENA is not unexpected but merely an incidental epiphenomenon, since the same strategies are found across dialects, but 
the difference is the morphological marking, particularly that of s, which is not sensitive to prominence scales in the first place.

The same holds for pronominal objects, which can be expressed by a preposition independent of the verb or by verbal person markers. The main difference among dialects can be the expression of s, as is illustrated in (37) below. Both accusative verbal person marking, as represented in Jewish Arbel (NE Iraq) and ergative verbal person marking, as represented in Jewish Sulemaniyya (NE Iraq), are restricted to the third person, and the unrestricted alternative independent objects are the same, but only the choice of person marking in the intransitive (37a) is distinct. The independent expression by the 'all-series is favored when no dependent person markers, i.e. the E-set, are available, whereby the prepositional marking system penetrates the verbal person marking system. Consequently, the main difference between these two dialects is the coding of s. This concurs with Siewierska's (2004, 46-47, 6o-61) typological survey: cross-linguistically, object person markers tend to be coded independently, and independent person markers, if restricted, typically refer to human referents. The ergative-tripartite person split is consistent with the person scale, since the marking of $\mathrm{S}$ and $\mathrm{P}$ groups the lower ranking persons. Nevertheless, tripartite alignment is equally attested for the third person (i.e. qțal-le 'alla 'He killed her'), which contradicts the person scale, and the same restrictions apply to the accusative pattern in $(37 \mathrm{a}-\mathrm{d})$, which indicates that a split along the person scale may have nothing to do with ergativity.

(37) Accusative and tripartite compared
J. Arbel (Khan 1999)
J. Sulemaniyya (Khan 2004a, 2007a)
ACCUSATIVE ( $3^{\text {RD }}$ ONLY)
$\left[\begin{array}{ll}\mathrm{v} & -\mathrm{s}\end{array}\right]$
ERGATIVE ( ${ }^{\text {RD }}$ ONLY)
[v-s]

a. $q \partial m$

$-l a$

'She rose.'

e. qim- $\boldsymbol{a}$

'She rose.'

b. $\left.\begin{array}{ll}\mathrm{V}-\mathrm{P} & -\mathrm{A}\end{array}\right]$

'He killed her.'

ACCUSATIVE

$[\mathrm{V}-\mathrm{A}] \quad[\mathrm{P}]$

c. qtal-le 'allax

'He killed you ${ }_{\mathrm{FS}}$ '
TRIPARTITE

$[\mathrm{V}-\mathrm{A}] \quad[\mathrm{P}]$

g. qțal-le 'allax

'He killed you ${ }_{\mathrm{FS}}$ ' 

[V-s]
[v-s]
d. qam-lax
h. qim-at
'You ${ }_{\mathrm{FS}}$ rose.'
'You ${ }_{\mathrm{FS}}$ rose.'

Similarly, the fundamental difference between the morphologically nondistinct, i.e. neutral, and horizontal verbal person marking may also be the coding of s: while the transitive constructions are similar, the intransitive constructions are distinct, as contrasted in (38) below. In Turoyo (SE Turkey), and arguably the Jewish dialects of NENA in West Iran like Saqiz and Sanandaj, horizontal alignment is confined to first/second person arguments alternating with ergative for the third person. Morphologically non-distinct marking is necessary for first/second person markers in the Northern Trans-Zab Jewish dialects of NENA, such as J. Urmi, and this alternates with accusative for the third person only. The fact that neutral alignment is preferred also shows that the differential marking is not geared to disambiguate between $\mathrm{A}$ and $\mathrm{P}$ in phonological form.

(38) Neutral and horizontal compared
J. Urmi (Khan 2008b)
Ṭuroyo (Miden, cf. Jastrow 1985)
ACCUSATIVE (3RD ONLY)
ERGATIVE (3RD ONLY)
$\left[\begin{array}{ll}\mathrm{v} & -\mathrm{s}\end{array}\right]$
$\left[\begin{array}{ll}\mathrm{V} & -\mathrm{s}\end{array}\right]$

a. qam $\quad-$ a

'She rose.'

b. qayim -o

'She rose.'

$\left.\begin{array}{ll}{[\mathrm{V}-\mathrm{P}} & -\mathrm{A}\end{array}\right]$

'He saw her.'

NEUTRAL

[V-A-P]

d. $x z e ́-l i-l a x$

'I saw you ${ }_{\mathrm{FS}}$.'

[v-s]

e. qam-lax

'You ${ }_{\mathrm{FS}}$ rose.'
$\left[\begin{array}{lll}\mathrm{V} & -\mathrm{P} & -\mathrm{A}\end{array}\right]$

f. hazy - o

'He saw her.'

HORIZONTAL (1ST/2ND ONLY)

[V-A-P]

g. haé-li-lax

'I saw you ${ }_{\mathrm{FS}}$ '

[v-s]

h. qayim-at

'You ${ }_{\mathrm{FS}}$ rose.'

A morphologically very different phenomenon is the qam-qațl-formation to express the preterit, illustrated in (39) below. Nevertheless, functionally, it is a type of differential object marking in that first/second person objects need 
to be marked by the L-set for which the qam-qațl-preterit is necessary. The qtil-preterit, by contrast, is again available only for the third person. Differential object marking has at least partly motivated the construction of an entirely distinct verbal form dedicated to the higher ranking $P$ arguments. Although the qam-qațal-stem is based on the transitive morphosyntax of qațal-, it is confined to transitive perfective past clauses and functions as the equivalent to qtal-le with a pronominal object. This resulting system in (39c) makes a morphosyntactic distinction between $\mathrm{S}$ and $\mathrm{A}$, but not between $\mathrm{S}$ and $\mathrm{P}$, which points to a person-unrestricted ergative against a person-restricted accusative pattern.

(39) qțil- and qam-qațal-preterit compared

J. Zaxo (based on Cohen 2012, 458-465)

ACCUSATIVE (3RD ONLY)

$\left[\begin{array}{ll}\mathrm{v} & -\mathrm{s}\end{array}\right]$

a. $q \partial m \quad-l a$

'She rose.'

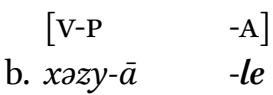

'He saw her.'

ERGATIVE

$\left[\begin{array}{ll}\mathrm{V}-\mathrm{A} & -\mathrm{P}\end{array}\right]$

c. qam-xāzy-a -lax

'She saw you ${ }_{\mathrm{rs}}$ '

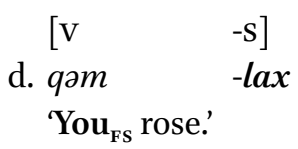

Ergativity in itself therefore plays no role in the constructional preferences for person referents, which may be simply the result of the collapse of the inverted preterit due to cross-system harmonization that has targeted first/second person objects first.

\subsubsection{Agent-Related Scales}

While $\mathrm{P}$ and $\mathrm{R}$ can be marked by various prepositions, $\mathrm{A}$, if applicable in the dialect, can be marked only by the preposition $l$ - and/or its allomorphs. Historically, such dative agents and L-suffixes were similar instances of the same preposition of nominal and pronominal arguments, respectively. 
The special l-marking of A in Turoyo is optional and always combined with overt A indexing, sometimes conditioned by agent focus, especially when A is pronominal. Zero coding is also found for A arguments in focus, but overt marking of pronominal As strongly correlates with agent focus. This agent focalization is reminiscent of other languages that show differential or optional Amarking. This flagging of A is combinable with differential ergative indexing or additional flagging of Ps. The co-variation between an overtly and zero-coded A closely resembles other constructions, where the argument is marked by $l$-, including possessors and experiencers. ${ }^{14}$

A less clear, but also possible instance of focal A-marking is attested in NENA dialects where the L-suffixes group $\mathrm{s}$ and $\mathrm{A}$ in the preterit. This agentless 'perfective' construction in these dialects is possibly similar to languages such as Konjo (Friberg 1996) where agent agreement is absent when A is focal (Siewierska 2004, 160-162). The absence of agreement in itself cannot be connected with agent focus in NENA, but when the agent is a full nominal, only P is indexed and the A index must be lacking in order to focalize it and mark it by the preposition ('əl-)l- (see $\S 4.2$.$) . This is a major difference from the aforementioned$ pattern in Țuroyo, where flagging of A is always combined with indexing of A (see $\S 5.2 .2$.$) .$

Overt indexing of A may also be more obligatorily absent: in the compound realis perfect of Jewish dialects of NENA in West Iran, A is confined to the third person and never realized overtly, while overt marking of $P$ is possible and may involve all persons (see § 3.4.7.). As expected, therefore, the ergative pattern is confined to lower ranking persons, but, here, it is dependent on the person reference of $\mathrm{P}$ and $\mathrm{A}$. No such restrictions are found for $\mathrm{s}$ and a tripartite pattern is found when $\mathrm{A}$ is first/second person.

Furthermore, verbal constructions can depend on the animacy of $\mathrm{A}$ in the Southeast Trans-Zab Jewish varieties that group $\mathrm{s}$ and $\mathrm{P}$ by the E-set. This is restricted and also lexically motivated by the meaning of the verb: a nonhuman agent receives intransitive coding distinct from $\mathrm{A}$, while a human agent receives the transitive coding of $\mathrm{A}$. This demonstrates that inanimate arguments are not always compatible with the A function and require an intransitive verbal construction instead, and as a consequence it is the lower ranking argument, i.e. inanimates, that favor marking distinct from A (see §.3.5.2.2.).

Moreover, a higher person reference of A is blocked from the $q$ țil-a-le-forms in some NENA varieties, when $P$ is also of higher ranking (see $\S$ 4.4.1.2.). The relatively lower ranking of $\mathrm{A}$ is presumably significant in the compatibility of a

14 See Noorlander (2021). 
situation with the inverted transitive perfective. When P outranks A in person, the use of the E-series in qțil-a-le seems to be more acceptable for speakers of an otherwise person-restricted construction, whereas, when both A and $\mathrm{P}$ are high in ranking, the construction remains impossible. Typologically, we would not expect the situation where P outranks a to be favored in an otherwise restricted construction.

Special marking of A may also be solely dependent on its person reference: if my analysis is correct, the first/second person are expressed by means of an L-E-series that results in an ergative pattern in the Christian dialect of Artun (Hertevin, SE Turkey) as well as partly in C. Umṛa and Jinnet (see § 4.4.4.). Typologically, C. Artun shows a rather complex agreement system in qțil-, since the $3 \mathrm{~ms}$., $3 \mathrm{fs}$. and $3 \mathrm{pl}$. are morphologically non-distinct and the $3 \mathrm{fs}$. and $3 \mathrm{pl}$. can pattern accusatively. The ergative, in turn, is restricted to the other persons, which would be an important counterexample to the predictions of the person scale, since it is the highest ranking arguments that pattern ergatively, while the lower ranking persons do not, nor independent pronouns and full nominals.

Perfective transitive clauses with an object index can be treated very differently from those without: this creates a constructional split, primarily motivated by the properties of $\mathrm{P}$, but also affecting the coding of $\mathrm{A}$. Without an object index, A agreement is indistinct from s agreement. A co-referential nominal object is not obligatory and, if indefinite, even impossible in such constructions. The first/second person L-E-series in C. Artun only manifest themselves in the combination with a dependent object person form, which may crossindex a co-referential NP. Similarly, the qam-qațl-construction also requires fully transitive coding, but, contrary to the L-E-series, the marking of A and $\mathrm{P}$ are only conditioned by the pronoun-noun hierarchy, i.e. both have to be cross-indexes, and not the person hierarchy, i.e. all persons are compatible. In addition, compound verbal forms analogical to qațal- treat such transitive clauses differently, and this affects the coding of A, especially with first/second person objects (see § 3.1.3.3. and § 4.3.2.4.). The adaptation to qatal- presumably normalizes the use of the L-set to mark the object. The merger of the compound perfect with qațal-also yields forms virtually identical to that of qtil-, as shown in (40) below. Such perfect and pluperfect ms. forms would be phonologically identical to equivalent preterit and plupreterit constructions with the opposite roles. The qtil-constructions such as the perfect in C. Borb-Ruma (Bohtan) in (41) below, which match the inflection of qațal- both in form and function, do not show any person role constraints (see $\$$ 4.4.3.2.), and as a result of this the distinct marking of $\mathrm{A}$ is tense-aspect sensitive, e.g. qțal-li 'I killed' vs. qțil-ən 'I $\mathrm{I}_{\mathrm{M}}$ have killed'. 
(40) J. Urmi (NW Iran; based on Khan 2008b)

$$
\begin{aligned}
& \text { PERFECT }\left({ }^{+} q t i l a+\mathrm{E}_{1} \text {-set }\right) \quad \text { PRETERIT }\left({ }^{+} q t i l-+\mathrm{E}_{1} \text {-set }\right) \\
& { }^{+} \text {qtil-an-ne } \\
& \text { : }{ }^{* *+} \text { qtil-an-ne } \\
& \text { 'I } \mathrm{I}_{\mathrm{M}} \text { have killed him.' } \\
& \text { 'He killed } \mathbf{m e}_{\mathrm{M}} \text {.' } \\
& { }^{+} \text {qtil-án-wa-le } \\
& \text { : **+qtil-án-wa-le } \\
& \text { 'I }{ }_{M} \text { had killed him.' } \\
& \text { 'He had killed } \mathbf{m e}_{\mathrm{M}} \text { ' }
\end{aligned}
$$

(41) C. Borb-Ruma (Bohtan, SE Turkey; based on Fox 20o9) PERFECT (qțil- + $\mathrm{E}_{1}$-set)

qțil-an-ne

'I $\mathrm{I}_{\mathrm{M}}$ have killed him.'

qțil-an-wó-le

'I $\mathrm{M}_{\mathrm{M}}$ had killed him.' 